\title{
SKILLS MISMATCH AND WAGE INEQUALITY: EVIDENCE FOR DIFFERENT COUNTRIES IN EUROPE
}

\author{
Marcelo SANTOS, Tiago Neves SEQUEIRA \\ CEFAGE-UBI Research Unit, University of Beira Interior, Covilhã, Portugal
}

\begin{abstract}
This paper studies the relationship between mismatch between workers' skills and labour market requirements throughout different European Countries. It reports evidence that in several countries, over-skilled people tend to have a wage penalty and under-skilled people tend to have a premium. Interestingly, despite the typical effects of education, tenure, experience, and gender in wages being very similar, the effects of mismatch between skills and labour market requirements differ considerably across the wage distribution and the European Countries.
\end{abstract}

Keywords: education, educational mismatch, wage inequality.

Reference to this paper should be made as follows: Santos, M.; Sequeira, T. N. 2013. Skills mismatch and wage inequality: evidence for different countries in Europe, Technological and Economic Development of Economy 19(Supplement 1): S425-S453.

JEL Classification: I21; J31; O52.

\section{Introduction}

We study wage regressions, introducing coefficients that measure mismatch between skills and jobs features. The data used are from the European Working Conditions Survey, 2005 wave, allowing us to compare several European countries. There is a considerable body of literature on the effects of mismatch between education, skills, and job placements on wages. Muysken and Ter Weel (2000) develop a search-theoretical model of the labour market to explain the events of declining returns to schooling, over-education, and relatively higher unemployment rate of the low-skilled workers in the Netherlands. Guironnet and Peypoch (2007) find empirical evidence of over-education for low-skill French workers, while also finding a significant disequilibrium between wages and qualifications. Dolton and Silles (2008) seek evidence of over-education, and assess its main determinants in the UK. Cardoso

Corresponding author Tiago Neves Sequeira

E-mail: sequeira@ubi.pt 
(2004) found no evidence of over-education in the Portuguese labour market. McGoldrick and Robst (1996) found no evidence for differential over-education by gender. Sicherman (1991) characterizes overeducated workers. Overeducated workers are found to be younger, to have less on-the-job training, and higher rates of firm and occupational mobility. The findings suggest that over-education can be explained by the trade-off between schooling and other components of human capital and by the mobility patterns. Regarding the type of education, Robst (2007) analyses the relationship between college majors and job functions using US data. Substantial evidence of mismatch between jobs and college major was found, and this was reflected in lower wages.

As Rubb (2003) pointed out, the empirical literature until the time of his writing had presented evidence of a positive effect of over-education, less than the effect of required education and a negative effect of under-education on wages. Included in his literature review are Cohn and Kan (1995), Kiker et al. (1997), Sloane et al. (1999), and Hartog (2000), and many others. Tsai (2010) presents results for a panel data analysis of the US and argues that over-education does not cause lower earnings, as suggested in earlier studies. Instead, the significant wage differential found in those earlier studies is simply a result of ignoring the non-random assignment of workers to jobs. Ordine and Rose (2011) suggest the importance of schooling quality as a policy instrument to reduce mismatch. There is still a discussion in the literature concerning the reasons for the effects of over-education and over-skilling on wages. One of the reasons that have been argued is linked with the omission of skills variables in wage regressions. The argument is that some workers end up being lower paid than others because, despite being better educated (have more years of schooling), they do not have the skills that are well-rewarded in the market, while the others do. Thus, the underlying cause for these effects on wages would be omitted heterogeneity in the empirical frameworks.

However, more recently McGuiness and Sloane (2011) studied mismatch in the UK labour market and concluded that over-education and being over-skilled imply a wage penalty. Note that according to these authors, over-skilling has stronger negative effects on job satisfaction than over-education, which may suggest a trade-off between wage and other characteristics of the job. These authors conclude that it is over-skilling on which the policy focus should be, as this represents welfare losses to both the individual and the economy as a whole. We follow this line of thought by centring our analysis on skills (rather than education) mismatches. The different effects from mismatch in education and mismatch in skills has been addressed by Alen and Velden (2001), McGuiness and Sloane (2011), while Tsang and Levin (1985) relied on the psychology literature to argue that workers with jobs requiring more education often exhibit counterproductive behaviour in the workplace, an argument easily extended to over and under-skilled workers.

Lamo and Messina (2010) confirmed that the over-educated have lower wages in Estonia, attributing this effect to a transition period. Budria and Moro-Egido (2008) found evidence of over-skilling in the Spanish labour market. However, only strongly mismatched workers had a significant wage penalty. Moreover, these authors showed that matched workers have significantly higher returns to education than do mismatched workers.

We extend the empirical work presented so far by showing evidence from a large sample of European countries with a single methodology, and concentrate our efforts on mismatch in skills. This follows the Budria and Moro-Egido (2008:341) suggestion: “To our eyes, assessing 
the impact that educational mismatches have in the European wage structure is a compelling task for future research.” As these authors did, we also study the mismatch influence on wages throughout the distribution of wages, thereby examining its effect on wage inequality. Interestingly, we found that the pattern of the mismatch effect in wages differs considerably across European labour markets. We also found that the most common significant result is that under-skilling positively influences wages, while over-skilling negatively influences wages. However, this also varies across wage distributions within each country. While the finding that over-skilling negatively affects wages is relatively consistent in the literature (when compared with perfectly matched workers), the consistent finding that under-skilling positively affects wages is relatively newer, as earlier findings were that under-educated have a negative return (see e.g. Rubb 2003).

The article proceeds as follows. Section 1 presents data and the estimating model. Section 2 presents the results and is divided into three sub-sections: Section 2.1 presents the results for the usual variables (education, experience, tenure, etc.) in wage regressions; Section 2.2. details the results on the effects of over and under-skilling on wages; and Section 2.3. presents the results from a pooled regression with all the countries. The final section concludes the study.

\section{Data and estimating model}

We collected data from the 2005 wave of the European Working Conditions Survey ${ }^{1}$ (EWCS) (Eurofound 2012) for 31 European countries: Austria, Belgium, Bulgaria, Croatia, Cyprus, Czech Republic, Denmark, Estonia, Finland, France, Germany, Greece, Hungary, Ireland, Italy, Latvia, Lithuania, Luxembourg, Malta, Netherlands, Norway, Poland, Portugal, Romania, Slovakia, Slovenia, Spain, Sweden, Switzerland, Turkey, and the United Kingdom. This survey was conducted under the supervision of the European Commission and follows the well-known survey "European Community Household Panel (ECHP)", which ended with the 2001 wave.

This survey contains personal and labour market characteristics including wage, hours worked, gender, marital status, experience, tenure, ISCED education levels and sector of the firm, among other variables. Table 1 summarizes the variables used and their respective definitions. The database also has the data that come from a question asking the respondent whether he/she has the training to deal with his/her current duties. The respondent answers if his/her skills correspond to his/her work duty [" 1 " I need further training to cope well with my duties; "2" My duties correspond well with my present skills; "3" I have the skills to cope with more demanding duties; " 8 " no opinion; "9" refuses to answer]. We eliminated answers 8 and 9 and interpret answer " 1 " as under-skilling and answer " 3 " as over-skilling, while answer " 2 " is a correct match between education/skills and work duties or requirements. This yields somewhat different information about mismatches from that offered by the former European Household Community Panel, which was used to study mismatches in the Spanish labour market by Budria and Moro-Egido (2008). The most important difference is that in our case (EWCS) there is no information about whether the skills that the question

\footnotetext{
http://eurofound.europa.eu/ewco/surveys/
} 
refers to were acquired through formal training and education or not. We therefore refer to mismatch in skills and not to mismatch in education.

Table 1. Variables and measurement

\begin{tabular}{|c|c|c|c|}
\hline Variables & Variables at the regression & Definition & Measure \\
\hline Wages & Wages & $\begin{array}{l}\text { Monthly income mea- } \\
\text { sured by deciles (divided } \\
\text { by } 10 \text { parts, each part } \\
\text { corresponds to a group of } \\
\text { income of each country) }\end{array}$ & $\begin{array}{l}\text { “01” A; “02” B; “03” C; } \\
\text { “04” D; “05” E; “06” F; } \\
\text { “07” G; “08” H; “09” I; } \\
\text { "10” J. }\end{array}$ \\
\hline Education & $\begin{array}{l}\text { edu0 (dummy for ISCED0); } \\
\text { edu1 (dummy for ISCED1); } \\
\text { edu2 (dummy for ISCED2); } \\
\text { edu3 (dummy for ISCED3); } \\
\text { edu4 (dummy for ISCED4); } \\
\text { edu5 (dummy for ISCED5); } \\
\text { edu6 (dummy for ISCED6). }\end{array}$ & $\begin{array}{l}\text { International Standard } \\
\text { Classification of Educa- } \\
\text { tion (ISCED) }\end{array}$ & $\begin{array}{l}\text { “0” ISCED0; “1” ISCED1; } \\
\text { "2” ISCED2, “3” ISCED3, } \\
\text { “4” ISCED4, “5” ISCED5, } \\
\text { "6” ISCED6. }\end{array}$ \\
\hline $\begin{array}{l}\text { Expe- } \\
\text { rience }\end{array}$ & $\begin{array}{l}\text { exper; exper2 } \\
\text { (experience squared) }\end{array}$ & $\begin{array}{l}\text { Number of years that } \\
\text { respondent stopped } \\
\text { full-time education and } \\
\text { started a paid employment }\end{array}$ & Number of years. \\
\hline Tenure & Tenure & $\begin{array}{l}\text { Number of years that } \\
\text { respondent is working at } \\
\text { the company }\end{array}$ & $\begin{array}{l}\text { "00" if less than } 1 \text { year; } \\
\text { Number of years otherwise. }\end{array}$ \\
\hline Age & Age & Age of respondent & Number of years. \\
\hline $\begin{array}{l}\text { Marital } \\
\text { Status }\end{array}$ & $\begin{array}{l}\text { MaritalStatus (dummy } \\
\text { for married) }\end{array}$ & $\begin{array}{l}\text { Relationship of respon- } \\
\text { dent to other members of } \\
\text { his/her household }\end{array}$ & $\begin{array}{l}\text { "01" spouse/partner; } \\
\text { "00" other. }\end{array}$ \\
\hline Gender & Gender & Gender of Respondent & "1" for male; " 2 " for female \\
\hline Firm Size & FirmSize & $\begin{array}{l}\text { Company size, which is } \\
\text { measured by number of } \\
\text { employees that respon- } \\
\text { dent's workplace has }\end{array}$ & 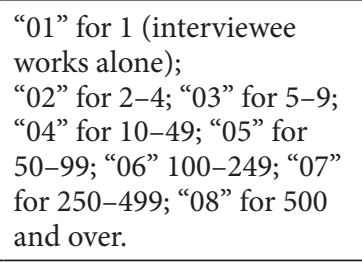 \\
\hline $\begin{array}{l}\text { Firm } \\
\text { Sector }\end{array}$ & FirmSector & $\begin{array}{l}\text { Sector that respondent } \\
\text { works in }\end{array}$ & $\begin{array}{l}\text { "1" private sector; " } 2 \text { " } \\
\text { public sector; "3" joint } \\
\text { private-public organization } \\
\text { or company; } \\
\text { "4" non-for-profit sector, } \\
\text { NGO; "5" other. }\end{array}$ \\
\hline $\begin{array}{l}\text { Under- } \\
\text { skilling }\end{array}$ & $\begin{array}{l}\text { mis1 (dummy for } \\
\text { underskilling) }\end{array}$ & $\begin{array}{l}\text { Respondent answers if } \\
\text { his/her skills correspond } \\
\text { to his/her work duty }\end{array}$ & $\begin{array}{l}\text { "1" I need further training } \\
\text { to cope well with my duties; } \\
\text { "0" Other answers. }\end{array}$ \\
\hline
\end{tabular}


Continued Table 1

\begin{tabular}{llll}
\hline Variables & Variables at the regression & \multicolumn{1}{c}{ Definition } & \multicolumn{1}{c}{ Measure } \\
\hline $\begin{array}{l}\text { Over- } \\
\text { skilling }\end{array}$ & $\begin{array}{l}\text { mis3 (dummy for } \\
\text { overskilling) }\end{array}$ & $\begin{array}{l}\text { Respondent answers if } \\
\text { his/her skills correspond } \\
\text { to his/her work duty }\end{array}$ & $\begin{array}{l}\text { "1" I have the skills to cope } \\
\text { with more demanding } \\
\text { duties; } \\
\text { "0" Other answers. }\end{array}$ \\
\hline
\end{tabular}

Note: Non-responses, refusals, and non-opinion were deleted from the analysis

Additionally the income-related variable in ECWS is Monthly income measured by deciles (divided by 10 parts, each part corresponding to an income group for each country). EWCS justifies the earnings definition as follows. Giving the respondents a scale on which they can place themselves tends to produce higher response rates than enquiring directly about earnings. The problem facing international surveys, however, is how to make the scales meaningful in each country (by adapting them to the national pay levels) but also comparable internationally. The Foundation's approach to this issue in the fourth European Working Conditions Survey was to ensure that the national 10-point scales roughly matched the real distribution of earnings. Using Eurostat's European Earnings Structure Survey 2002, the earnings of each EU country were divided into 10 bands (called 'deciles', each representing $10 \%$ of the respondents), and ranked from low to high (Parent-Thirion et al. 2007).

This yields a better comparison between countries. Although differing substantially in the information provided, this is currently one of the most complete databases on labour information for Europe.

We estimated the following earnings equation:

$$
w_{i}=\alpha_{0}+\alpha_{\theta_{1}} X_{i}+\alpha_{\theta z} m i s 1+\alpha_{\theta z} m i s 3,
$$

where the subscript $\theta$ denotes the estimate at the $\theta^{\text {th }}$ conditional quantile, in which $\theta=10,25,50$, 75 , and 90 . The dependent variable, $w_{i}$, is the ECWS variable for wage, and $X_{i}$ is a vector of explanatory variables, including education dummies, corresponding to the different ISCED levels ${ }^{2}$, experience (and experience squared), tenure, gender, sector, and firm size. mis 1 is a dummy variable that takes 1 if the answer to the question mentioned above was 1 , i.e. 'I need further training to cope well with my duties', and mis 3 is a dummy variable that takes 1 if the answer to the question mentioned above was 1, i.e. 'I have the skills to cope with more demanding duties'.

As usual in labor market studies, and in particular with the estimation of earnings equations, we use OLS estimation. To allow for assessing the effect of different determinants of earnings and specifically of mismatch on the wage distribution, we also employ quantile regressions (Koenker, Hallock 2001). In this article, we employ the design matrix bootstrap method to obtain estimates of standard errors for the coefficients, with 100 interactions. This method is robust to relatively small samples and more importantly, it is valid under many forms of heterogeneity (Buchinsky 1995, 1998). As there are no variables in the database that allows to access selection issues, we need to be clear that this model applies only to mismatch within the employed workers.

\footnotetext{
In an alternative specification we introduce education levels as given in the database (from 1 to 6 in most countries) and main results do not differ. We include education as dummies thanks to a referee's suggestion.
} 
The samples dimension for each country, as well as averages for the mismatch variables are detailed in Table 2.

\section{Results}

\subsection{General results from countries wage regressions}

Table 3 shows our results for the OLS and quantile (median) regressions, regarding the sign and statistical significance of the typical regressors. For the quantitative analysis we also refer the reader to the Tables in the Appendix that contain all of the coefficients and standard error values for all countries ${ }^{3}$.

Table 2. Number of observations and average for overskilling and underskilling for each country

\begin{tabular}{|c|c|c|c|c|c|c|c|c|}
\hline Country & $\begin{array}{l}\text { Austria } \\
\text { (1) }\end{array}$ & $\begin{array}{l}\text { Belgium } \\
\text { (2) }\end{array}$ & $\begin{array}{c}\text { Cyprus } \\
\text { (3) }\end{array}$ & $\begin{array}{l}\text { Czech } \\
\text { Rep. (4) }\end{array}$ & $\begin{array}{l}\text { Germany } \\
\text { (5) }\end{array}$ & $\begin{array}{c}\text { Denmark } \\
(6)\end{array}$ & $\begin{array}{c}\text { Estonia } \\
\text { (7) }\end{array}$ & $\begin{array}{c}\text { Spain } \\
(8)\end{array}$ \\
\hline obs & 610 & 687 & 551 & 659 & 839 & 924 & 446 & 695 \\
\hline $\begin{array}{l}\text { Mis1 } \\
\text { average }\end{array}$ & 0.2655738 & 0.1201158 & 0.0671506 & 0.1198786 & 0.2133492 & 0.1374459 & 0.190583 & 0.0604317 \\
\hline $\begin{array}{l}\text { Mis3 } \\
\text { average }\end{array}$ & 0.2114754 & 0.2836469 & 0.4065336 & 0.23217 & 0.250298 & 0.3203463 & 0.3251121 & 0.3482014 \\
\hline Country & $\begin{array}{l}\text { Finland } \\
\text { (9) }\end{array}$ & $\begin{array}{c}\text { France } \\
(10)\end{array}$ & $\begin{array}{l}\text { Greece } \\
\text { (11) }\end{array}$ & $\begin{array}{l}\text { Hungary } \\
(12)\end{array}$ & $\begin{array}{l}\text { Ireland } \\
\text { (13) }\end{array}$ & $\begin{array}{l}\text { Italy } \\
(14)\end{array}$ & $\begin{array}{l}\text { Lithuania } \\
\quad(15)\end{array}$ & $\begin{array}{c}\text { Luxem- } \\
\text { bourg(16) }\end{array}$ \\
\hline obs & 955 & 703 & 801 & 846 & 797 & 658 & 801 & 468 \\
\hline $\begin{array}{l}\text { Mis1 } \\
\text { average }\end{array}$ & 0.1385417 & 0.1026352 & 0.1223471 & 0.1134752 & 0.0991217 & 0.1458967 & 0.2197253 & 0.1374207 \\
\hline $\begin{array}{l}\text { Mis3 } \\
\text { average }\end{array}$ & 0.2072917 & 0.4757282 & 0.4007491 & 0.3817967 & 0.3801757 & 0.2948328 & 0.2284644 & 0.3784355 \\
\hline Country & $\begin{array}{l}\text { Latvia } \\
(17)\end{array}$ & $\begin{array}{l}\text { Nether- } \\
\text { lands(18) }\end{array}$ & $\begin{array}{l}\text { Malta } \\
\text { (19) }\end{array}$ & $\begin{array}{l}\text { Poland } \\
(20)\end{array}$ & $\begin{array}{l}\text { Portugal } \\
\text { (21) }\end{array}$ & $\begin{array}{l}\text { Sweden } \\
(22)\end{array}$ & $\begin{array}{c}\text { Slovenia } \\
\quad(23)\end{array}$ & $\begin{array}{c}\text { Slovakia } \\
\text { (24) }\end{array}$ \\
\hline obs & 796 & 823 & 488 & 706 & 747 & 994 & 469 & 814 \\
\hline $\begin{array}{l}\text { Mis1 } \\
\text { average }\end{array}$ & 0.144802 & 0.0933333 & 0.0997963 & 0.1600567 & 0.1137885 & 0.0611222 & 0.119403 & 0.1191646 \\
\hline $\begin{array}{l}\text { Mis3 } \\
\text { average }\end{array}$ & 0.3279703 & 0.3042424 & 03095723 & 0.3116147 & 0.2396252 & 0.4138277 & 0.3518124 & 0.3452088 \\
\hline Country & $\begin{array}{l}\text { UK } \\
(25)\end{array}$ & $\begin{array}{c}\text { Norway } \\
(26)\end{array}$ & $\begin{array}{l}\text { Switzer- } \\
\text { land (27) }\end{array}$ & $\begin{array}{l}\text { Bulgaria } \\
\quad(28)\end{array}$ & $\begin{array}{c}\text { Croatia } \\
(29)\end{array}$ & $\begin{array}{l}\text { Romania } \\
\quad(30)\end{array}$ & $\begin{array}{c}\text { Turkey } \\
\text { (31) }\end{array}$ & \\
\hline obs & 626 & 848 & 889 & 877 & 639 & 702 & 890 & \\
\hline $\begin{array}{l}\text { Mis1 } \\
\text { average }\end{array}$ & 0.0702875 & 0.1450472 & 0.1979753 & 0.0558723 & 0.1341654 & 0.1434659 & 0.1324355 & \\
\hline $\begin{array}{l}\text { Mis3 } \\
\text { average }\end{array}$ & 0.4376997 & 0.2735849 & 0.3104612 & 0.3295325 & 0.4477379 & 0.4346591 & 0.3445567 & \\
\hline
\end{tabular}

3 We present a synthesis in the main text to increase readability and in response to a referee's suggestion. 
First, we wish to analyse the results of the earnings regressions for each country in the light of the usual findings for earnings regressions that are reported in the literature. In fact, our results are clearly consistent with the usual findings, pointing to positive and significant effects of tenure on wages, together with the typical non-linear effect of experience and with a clear negative effect of gender (being a woman). Our results also reflect the importance of company size to the wage performance of workers, as larger firms tend to pay higher wages. Concerning education, nearly half of the countries show a significant positive sign for some of the education dummies and another half present negative and significant signs for some of the education dummies. As expected, negative signs predominate in dummies for the lowest levels of ISCED classification ${ }^{4}$. Tenure also has a clear and significant effect on wages in 25 of the 31 countries (exceptions are Croatia, Estonia, Finland, Slovenia, Sweden, and Turkey), with coefficients ranging from 0.019 to 0.087 , meaning that an additional year of tenure implies a $0.2 \%$ to a $0.87 \%$ increase in wages. Experience and squared experience are also significant in almost all countries (in 29 out of the 31 countries), with Slovenia and Romania as exceptions. Coefficients oscillate from 0.069 to 0.23 , meaning that an additional year of experience implies a $0.69 \%$ to $2.3 \%$ increase in wages. However, after some years, experience also presents the typical negative effect. For example, in Germany, after nearly 29 years of experience, additional years tend to decrease the worker wage. In the Czech Republic, however, this occurs after 17 years of experience.

Gender has a significantly negative effect in all countries with a quantitatively important effect, as being a woman means earning from $6.4 \%$ less (in Turkey) to nearly $27 \%$ less in the Netherlands. Interestingly, countries with a lower wage penalty for female are eastern European countries (Croatia, Hungary, Romania, and Slovenia) ${ }^{5}$ Age is less significant than the above mentioned variables, but it has a negative and significant sign in 14 of the 31 countries. When significant, its effects range from a 0.2 to $1.1 \%$ decrease in wages per additional year. Marital status tends to influence wages positively in 14 out of 31 countries, a quantitative wage premium that ranges from nearly $3 \%$ to $5 \%$ from being married.

Finally, firm size has an overall significantly positive effect on wages (exceptions are Croatia, the Czech Republic, and Slovenia), as an increase in the size class of the firm would imply an increased wage of $1 \%$ to $3.6 \%$. Estonia, Romania, and Sweden are among the countries in which the effect of firms' size is greatest. As can be seen in Table 3 , the effect of mismatch is generally the least significant of the explanatory variables in the regressions, an issue that we will address below.

Our results from the quantile regression at the median almost confirm the OLS regression results, concerning both significance and quantitative effects (Table 3$)^{6}$. Most countries show

4 Had we presented an alternative specification with education measured by ISCED levels and not dummies, education would have shown a clear and significant positive effect on wages, with coefficients that range from 0.20 (in Estonia) to 1.17 (in Croatia), meaning that one additional level of education (from primary to secondary, for example) implies that wages can increase from $2.0 \%$ to $11.7 \%$ (remembering that wages are measured by deciles of the wage distribution), results that are consistent with those usually obtained for returns to education. Results are available upon request.

5 There is an extensive literature on the wage gender gap. A survey can be found in Kunze (2000), in which one see that estimated gaps oscillate widely between $7 \%$ and $93 \%$.

6 Due to space considerations, we are not displaying regressions from other quantiles than the median. However, coefficients for mismatch throughout different quantiles are shown in figures below. 
a significantly positive effect of tenure (exceptions are now Denmark, Finland, Greece, Poland, Slovenia, and Sweden), experience (exceptions being Croatia, Estonia, the Netherlands, Slovenia, Romania, Turkey, and the UK), and firm size (exceptions being Austria, Croatia, the Czech Republic, Malta, and Slovenia); and significantly negative coefficients of experience squared (exceptions are Croatia, Hungary, the Netherlands, Poland, Romania, and Slovenia) and gender (no exceptions). The greatest difference from OLS is the more positive and significant signs of education dummies for 19 of 31 countries, in which negative signs are more linked with lower ISCED levels, which is an intuitive result ${ }^{7}$.

Table 3. Sign and statistical significance of typical determinants of wages (OLS, quantile - median regression)

\begin{tabular}{|c|c|c|c|c|c|c|c|c|c|}
\hline Var & Tenure & $\begin{array}{l}\text { Expe- } \\
\text { rience }\end{array}$ & $\begin{array}{l}\text { Expe- } \\
\text { rience }^{2}\end{array}$ & $\begin{array}{c}\text { Educa- } \\
\text { tion } \\
\text { Dum- } \\
\text { mies }^{*}\end{array}$ & Gender & $\begin{array}{l}\text { Firm } \\
\text { Size }\end{array}$ & Age & $\begin{array}{l}\text { Firm } \\
\text { Sector }\end{array}$ & $\begin{array}{c}\text { Marital } \\
\text { Status }\end{array}$ \\
\hline $\begin{array}{l}\text { Expected } \\
\text { Sign }\end{array}$ & $(+)$ & $(+)$ & $(-)$ & $(+)$ & $(-)$ & $(+)$ & $(-)$ & $\begin{array}{l}\text { Unde- } \\
\text { fined }\end{array}$ & $\begin{array}{l}\text { Unde- } \\
\text { fined }\end{array}$ \\
\hline Austria & $(+),(+)$ & $(+),(+)$ & $(-),(-)$ & $(-),(+)$ & $(-),(-)$ & $(+),(\mathrm{ns})$ & $(-),(\mathrm{ns})$ & $(-),(\mathrm{ns})$ & (ns), (ns) \\
\hline Belgium & $(+),(+)$ & $(+),(+)$ & $(-),(-)$ & $(-),(\mathrm{ns})$ & $(-),(-)$ & $(+),(+)$ & $(-),(\mathrm{ns})$ & (ns), (ns) & (ns), (ns) \\
\hline Cyprus & $(+),(+)$ & $(+),(+)$ & $(-),(-)$ & $(+),(+)$ & $(-),(-)$ & $(+),(+)$ & (ns), (ns) & $(\mathrm{ns}),(+)$ & (ns), (ns) \\
\hline $\begin{array}{l}\text { Czech } \\
\text { Rep. }\end{array}$ & $(+)(+)$ & $(+),(+)$ & $(-),(-)$ & $(+),(+)$ & $(-),(-)$ & $\begin{array}{l}\text { (ns), } \\
\text { (ns) }\end{array}$ & (ns), (ns) & (ns), (ns) & $(+),(\mathrm{ns})$ \\
\hline Germany & $(+),(+)$ & $(+),(+)$ & $(-),(-)$ & $(+),(+)$ & $(-),(-)$ & $(+),(+)$ & $(-),(\mathrm{ns})$ & $(-),(-)$ & (ns), (ns) \\
\hline Denmark & $(+),(\mathrm{ns})$ & $(+),(+)$ & $(-),(-)$ & $(+),(+)$ & $(-),(-)$ & $(+),(+)$ & $(-),(\mathrm{ns})$ & (ns), (ns) & $(+),(\mathrm{ns})$ \\
\hline Estonia & $(\mathrm{ns}),(+)$ & $(+),(\mathrm{ns})$ & $(-),(-)$ & $(-),(-)$ & $(-),(-)$ & $(+),(+)$ & $(-),(-)$ & (ns), (ns) & (ns), (ns) \\
\hline Spain & $(+),(+)$ & $(+),(+)$ & $(-),(-)$ & $(+),(-)$ & $(-),(-)$ & $(+),(+)$ & (ns), (ns) & (ns), (ns) & (ns), (ns) \\
\hline Finland & (ns), (ns) & $(+),(+)$ & $(-),(-)$ & $(-),(+)$ & $(-),(-)$ & $(+),(+)$ & (ns), (ns) & $(-),(\mathrm{ns})$ & $(+),(+)$ \\
\hline France & $(+),(+)$ & $(+),(+)$ & $(-),(-)$ & $(-),(\mathrm{ns})$ & $(-),(-)$ & $(+),(+)$ & (ns), (ns) & $(\mathrm{ns}),(\mathrm{ns})$ & $(+),(+)$ \\
\hline Greece & $(+),(\mathrm{ns})$ & $(+),(+)$ & $(-),(-)$ & $(+),(-)$ & $(-),(-)$ & $(+),(+)$ & (ns), (ns) & (ns), (ns) & $(+),(+)$ \\
\hline Hungary & $(+),(+)$ & $(+),(+)$ & $(-),(n s)$ & $(-),(-)$ & $(-),(-)$ & $(+),(+)$ & $(-),(\mathrm{ns})$ & $(-),(\mathrm{ns})$ & $(+),(\mathrm{ns})$ \\
\hline Ireland & $(+),(+)$ & $(+),(+)$ & $(-),(-)$ & $(-),(+)$ & $(-),(-)$ & $(+),(+)$ & $(-),(-)$ & (ns), (ns) & (ns), (ns) \\
\hline Italy & $(+),(+)$ & $(+),(+)$ & $(-),(-)$ & $(-),(-)$ & $(-),(-)$ & $(+),(+)$ & (ns), (ns) & (ns), (ns) & $(+),(+)$ \\
\hline Lithuania & $(+),(+)$ & $(+),(+)$ & $(-),(-)$ & $(+),(+)$ & $(-),(-)$ & $(+),(+)$ & $(-),(-)$ & $(-),(-)$ & (ns), (ns) \\
\hline $\begin{array}{l}\text { Luxem- } \\
\text { bourg }\end{array}$ & $(+),(+)$ & $(+),(+)$ & $(-),(-)$ & $(-),(-)$ & $(-),(-)$ & $(+),(+)$ & (ns), (ns) & (ns & (ns) \\
\hline Latvia & $(+),(+)$ & $(+),(+)$ & $(-),(-)$ & $(+),(-)$ & $(-),(-)$ & $(+),(+)$ & $(-),(-)$ & $(-),(-)$ & (ns), (ns) \\
\hline $\begin{array}{l}\text { Nether- } \\
\text { lands }\end{array}$ & $(+),(+)$ & $(+),(\mathrm{ns})$ & $(-),(\mathrm{ns})$ & $(+),(+)$ & $(-),(-)$ & $(+),(+)$ & (ns), (ns) & $(-),(-)$ & $(+),(n s)$ \\
\hline Malta & $(+),(+)$ & $(+),(+)$ & $(-),(-)$ & $(+),(+)$ & $(-),(-)$ & $(+),(\mathrm{ns})$ & (ns), (ns) & (ns), (ns) & $(+),(+)$ \\
\hline
\end{tabular}

Alternative specification with education measured by ISCED levels and not dummies, education has a clear and significant positive effect on wages, as described above in footnote 5 for OLS estimations, ranged, in the case of median regression, from a $2.5 \%$ to a $12.3 \%$ wage premium by ISCED level. 
Continued Table 3

\begin{tabular}{|c|c|c|c|c|c|c|c|c|c|}
\hline Var & Tenure & $\begin{array}{l}\text { Expe- } \\
\text { rience }\end{array}$ & $\begin{array}{l}\text { Expe- } \\
\text { rience }^{2}\end{array}$ & $\begin{array}{c}\text { Educa- } \\
\text { tion } \\
\text { Dum- } \\
\text { mies }^{*}\end{array}$ & Gender & $\begin{array}{l}\text { Firm } \\
\text { Size }\end{array}$ & Age & $\begin{array}{l}\text { Firm } \\
\text { Sector }\end{array}$ & $\begin{array}{c}\text { Marital } \\
\text { Status }\end{array}$ \\
\hline Poland & $(+),(\mathrm{ns})$ & $(+),(+)$ & $(-),(\mathrm{ns})$ & $(+),(+)$ & $(-),(-)$ & $(+),(+)$ & (ns), (ns) & (ns), (ns) & $(+),(n s)$ \\
\hline Portugal & $(+),(+)$ & $(+),(+)$ & $(-),(-)$ & $(+),(+)$ & $(-),(-)$ & $(+),(+)$ & (ns), (ns) & (ns), (ns) & $(+),(+)$ \\
\hline Sweden & (ns), (ns) & $(+),(+)$ & $(-),(-)$ & $(-),(+)$ & $(-),(-)$ & $(+),(+)$ & (ns), (ns) & $(-),(-)$ & (ns), (ns) \\
\hline Slovenia & (ns), (ns) & $\begin{array}{l}\text { (ns), } \\
\text { (ns) }\end{array}$ & (ns), (ns) & $(-),(+)$ & $(-),(-)$ & (ns), (ns) & (ns), (ns) & $(+),(-)$ & (ns), (ns) \\
\hline Slovakia & $(+),(+)$ & $(+),(+)$ & $(-),(-)$ & $(-),(-)$ & $(-),(-)$ & $(+),(+)$ & $(-),(-)$ & $(-),(\mathrm{ns})$ & $(+),(+)$ \\
\hline $\mathrm{UK}$ & $(+),(n s)$ & $(+),(+)$ & $(-),(-)$ & $(-),(-)$ & $(-),(-)$ & $(+),(+)$ & $(-),(\mathrm{ns})$ & $(-),(\mathrm{ns})$ & (ns), (ns) \\
\hline Norway & $(+),(+)$ & $(+),(+)$ & $\begin{array}{c}(-),(-) \\
(-)\end{array}$ & $(+),(-)$ & $(-),(-)$ & $(+),(+)$ & $(-),(-)$ & $(-),(-)$ & $(+),(\mathrm{ns})$ \\
\hline $\begin{array}{l}\text { Switzer- } \\
\text { land }\end{array}$ & $(+),(+)$ & $(+),(+)$ & $(-),(-)$ & $(+),(+)$ & $(-),(-)$ & $(+),(+)$ & (ns), (ns) & $(+),(+)$ & (ns), (ns) \\
\hline Bulgaria & $(+),(+)$ & $(+),(+)$ & $(-)$, (ns) & $(-),(+)$ & $(-),(-)$ & $(+),(+)$ & $(-),(-)$ & $(-),(-)$ & (ns), (ns) \\
\hline Croatia & (ns), (ns) & $(+),(\mathrm{ns})$ & $(-)$, (ns) & $(-),(+)$ & $(-),(-)$ & (ns), (ns) & (ns), (ns) & (ns), (ns) & (ns), (ns) \\
\hline Romania & $(+),(+)$ & (ns), (ns) & (ns), (ns) & $(+),(-)$ & $(-),(-)$ & $(+),(+)$ & (ns), (ns) & (ns), (ns) & (ns), (ns) \\
\hline Turkey & (ns), (ns) & $(+),(+)$ & $(-),(-)$ & $(-),(-)$ & $(-),(-)$ & $(+),(+)$ & $(-),(-)$ & $(+),(+)$ & $(+),(\mathrm{ns})$ \\
\hline
\end{tabular}

Note: in the first brackets are OLS results, second brackets are quantiles results, $(+)$ indicates positive and significant results, (-) to negative significant results and (ns) to non-significant results.

* $(+)$ refers to a majority of dummies with positive and significant sign, $(-)$ to a majority of dummies with negative and significant sign.

\subsection{The effect of mismatch in countries regressions}

The effect of mismatch between skills and labour market requirements on wages is non-significant in the majority of countries in both OLS and quantile regression on the median (Tables 3 and 4). From OLS results, we see that under-skilling (having fewer skills than required) is significant in Germany, Hungary, Slovenia, and Spain (with a positive effect of being under-skilled) and in Ireland, Latvia, and Turkey (with a negative effect of being under-skilled). Thus, we have significant results in only a quarter of the countries studied. Significant coefficients oscillate roughly from 0.5 to 1.1, meaning that, for instance, in Germany an under-skilled worker tends to earn $8.9 \%$ more than a correctly matched worker. Significantly negative coefficients are around 0.5, meaning that in Ireland under-skilled workers tend to earn nearly $6 \%$ less than a matched worker. Over-skilling appears with a positive significant effect in Hungary and Lithuania and with a negative significant effect in Denmark, Estonia, Latvia, Malta, the Netherlands, Portugal, Slovakia, and Turkey. Again, less than a third of the countries show a significant effect of mismatch. Significantly negative results oscillate from near 0.3 to near 0.5 , meaning that an over-skilled worker could earn $3 \%$ to $5 \%$ less than a matched worker. Additionally, the less common positive coefficients are 0.28 in Hungary and 0.58 in Lithuania, meaning that over-skilled workers earn $2.8 \%$ more in Hungary and 5.8\% in Lithuania than the respective matched counterparts. 


\section{Austria}

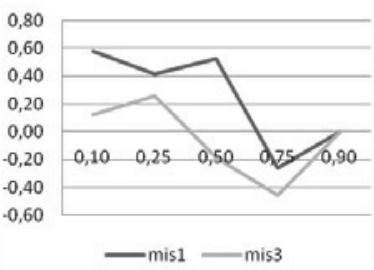

Germany

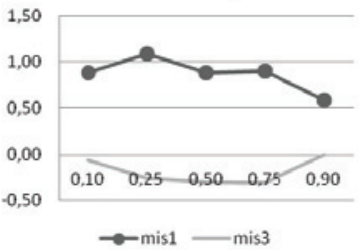

Czech Rep.

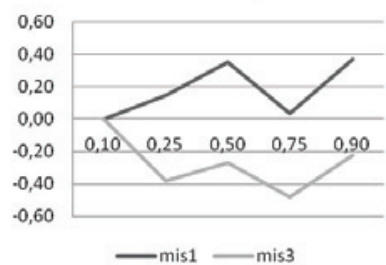

Greece

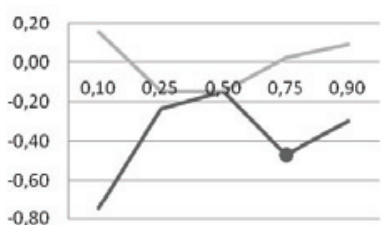

- mis1 mis3

France

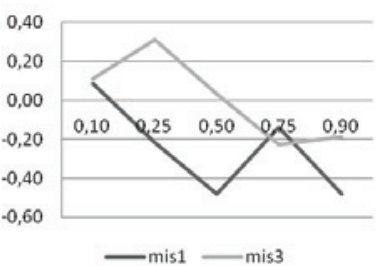

Latvia

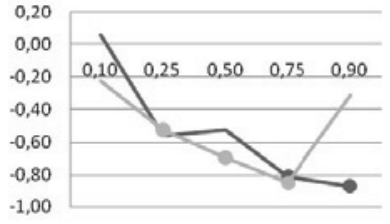

$\longrightarrow$ mis1 $m$ mis3
Cyprus

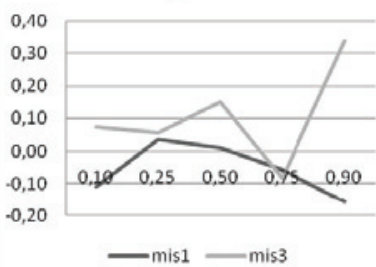

Estonia

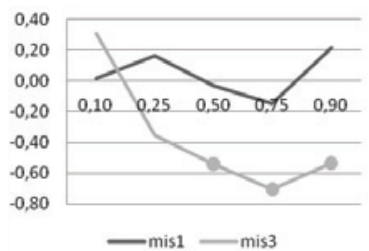

Finland

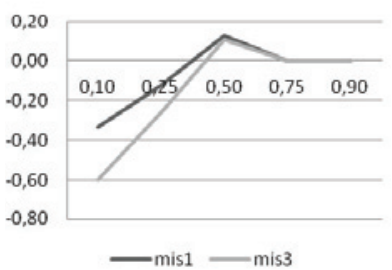

Ireland

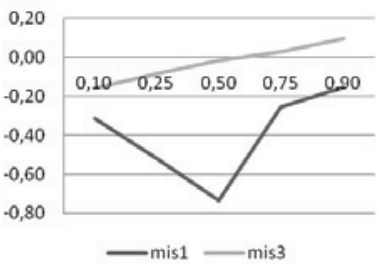

Lithuania

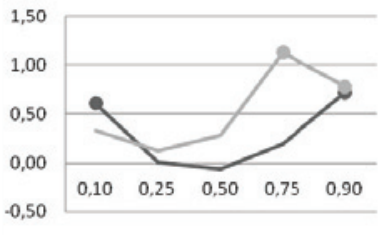

Malta

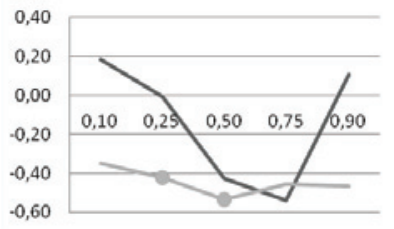

-mis1 mis3
Belgium

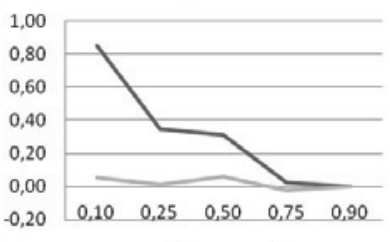

-mis1 mis3

Spain

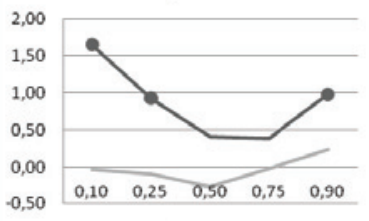

-mis1 -mis3

\section{Denmark}

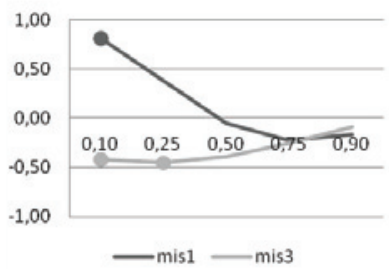

Italy

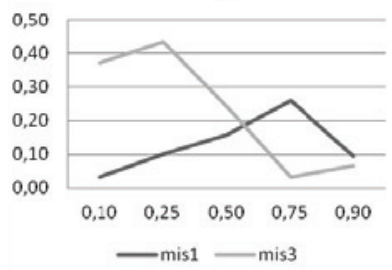

Hungary

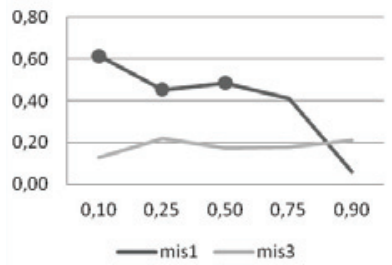

Poland

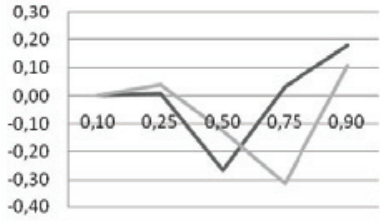

$\longrightarrow$ mis1 - mis3 
Luxembourg

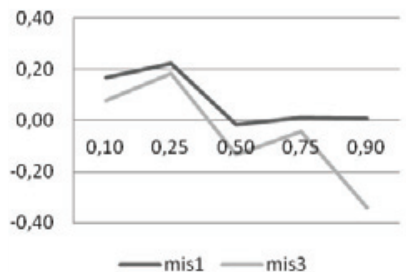

Slovenia

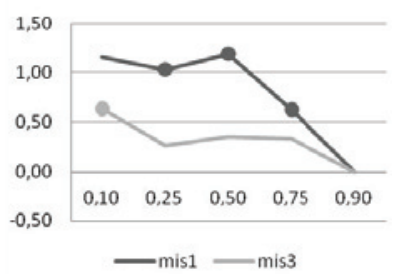

Sweden

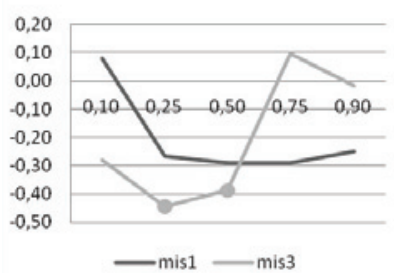

Switzerland

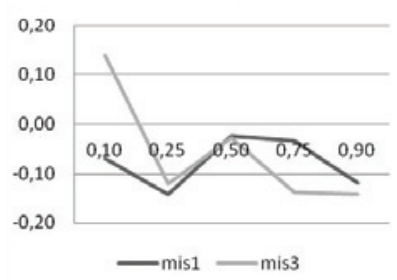

Romania

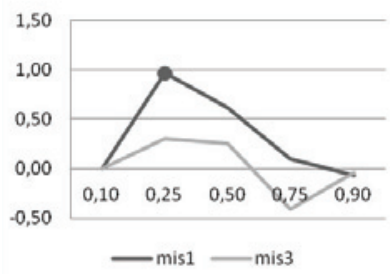

Portugal

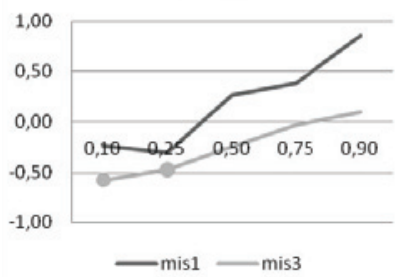

UK

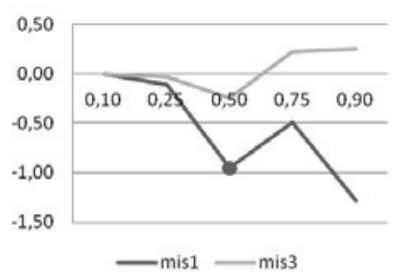

Croatia

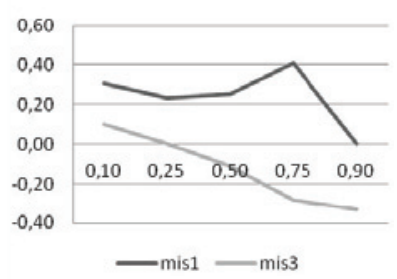

Bulgaria

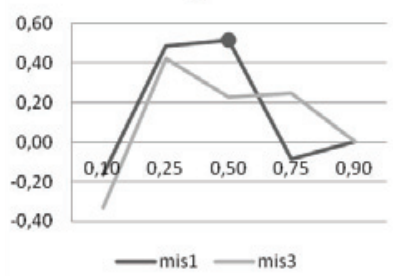

Netherlands

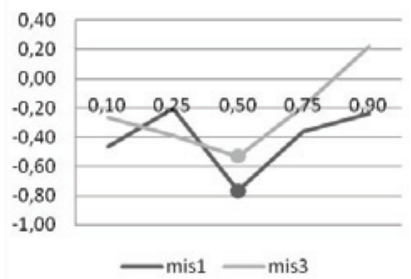

Norway

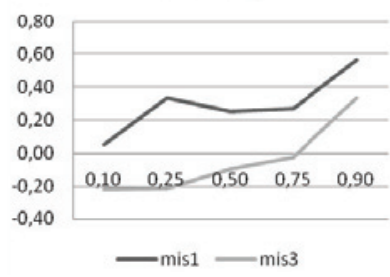

Slovakia

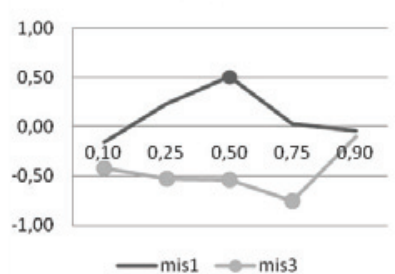

Turkey

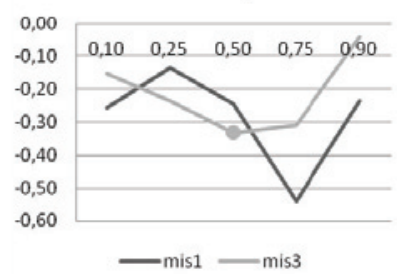

Fig. 1. Set of figures with the evolution of coefficients for under-skilling (mis1) and over-skilling (mis3) throughout the wage distribution for each country. Bullets in the graphs indicate statistically significant estimates (10\% or higher level of significance) 
We may note that these results are all conditional in the sense that those premiums and penalties should be read, for the same values of the other variables. This means that, for instance, over-skilled workers in Lithuania earn 5.8\% more than matched workers provided that they have the same level of education, the same years for tenure and experience, and work in firms of the same size in the same sector. The general picture is repeated when we observe results of the quantile regression on the median. In particular, Table 4 shows positive and significant under-skilling coefficients in Bulgaria, Germany, Hungary Slovakia, and Slovenia, with coefficients that oscillate between 0.5 and 1.19 , and with negative and significant effects in the Netherlands and UK. There are significantly negative effects of over-skilling in Estonia, Latvia, the Netherlands, Malta, Slovakia, Sweden, and Turkey (coefficients oscillate between -0.33 to -0.69 ) and with no country with positive significant effects.

Quantitatively, the effects of mismatch are important, because when significant, they are routinely higher than those effects from tenure, experience, and (in some cases) education. For instance, in Germany, while being under-skilled implies a wage penalty of $8.8 \%$, an additional year for tenure and experience implies respectively a $0.5 \%$ or $2.2 \%$ wage premium. For comparison, having the ISCED 2 education level implies a premium of $12.68 \%$ in this country.

The next step is to show and analyse the effect of mismatch (under-skilling and overskilling throughout the distribution of wages. For this, we plot a number of figures (Fig. 1) that indicate the value of coefficients.

As expected, there are differences in the influence of mismatch (under-skilling and over-skilling) across the wage distribution. However, the most common pattern continues to be one of a positive effect of under-skilling and a negative effect of over-skilling, a pattern present in Austria, Croatia, the Czech Republic, Estonia, Denmark, Germany, Portugal, Slovakia, and Spain, at least for the majority of the quantiles analysed ${ }^{8}$. The pattern according to which under-skilled workers tend to have lower wages and over-skilled workers tend to have higher wages throughout the distribution is mostly present in Cyprus, France, Greece, Lithuania, and the UK. A minority of countries show positive effects of under-skilling and over-skilling, such as Belgium, Hungary, Italy, and Slovenia and even fewer show negative effects of under-skilling and over-skilling (Latvia and Sweden).

If we restrict the analysis to the most significant results, noting that under-skilling has a significant positive wage premium in Germany throughout the entire distribution, significant results that also appear in Spain (for lower wages - quantiles 0.1 and 0.25 and for the highest quantile), for Denmark and Lithuania, just for the lowest quantile, Hungary (for the left-hand side of the wage distribution), and Slovenia (for intermediate quantiles of the wage distribution), Bulgaria and Slovakia for the median, and Romania for quantile 0.25 . A significant wage penalty for under-skilling is obtained for the 0.75 quantile in Greece, 0.9 in Latvia, and 0.5 in the Netherlands and the UK. There are significant wage penalties of over-skilling in the right-hand side of the wage distribution in Estonia and in the left-hand side of the distribution in Denmark and Portugal, in

\footnotetext{
We note that in most of the analysis that follows we may indicate effects that in fact are statistically non-significant. Miller and Rodgers (2008) discuss the importance of statistical significance versus economic significance. Although we will not take part in that discussion, we wish to provide information based on both statistical significance and economic significance, distinguishing between them.
} 
quantiles $0.25,0.5$, and 0.75 in Latvia, in quantiles 0.25 and 0.5 in Malta and Sweden, 0.5 in the Netherlands and Turkey, and 0.1 in Slovenia. In Slovakia, there is a significant wage penalty for over-skilling in almost all of the wage distribution (except in the 0.9 decile). The scarce wage premiums for over-skilling occurred in the right-hand side of the wage distribution in Lithuania (quantiles 0.75 and 0.9 ) and in the first decile of the wage distribution in Slovenia.

\subsection{Results from a pooled regression}

In this section we implement a pooled regression with country dummies ${ }^{9}$. Table 4 shows the results. This reinforces our main finding according to which under-skilling faces a wage premium and over-skilling faces a wage penalty.

Table 4. OLS and quantile regressions

\begin{tabular}{|c|c|c|c|c|c|c|}
\hline \multicolumn{7}{|c|}{ OLS } \\
\hline tenure & exper & exper2 & gender & age & firm sector & firm size \\
\hline $0.0383306^{* * *}$ & $0.1265561^{\star * *}$ & $-0.0022081^{* * *}$ & $-1.701237^{\star \star \star}$ & $-0.0269419^{* * *}$ & $-0.1793566^{\star * *}$ & $0.1874068^{* * *}$ \\
\hline$(0.0019479)$ & $(0.0050703)$ & $(0.0000811)$ & $(0.0318051)$ & $(0.002762)$ & $(0.0216065)$ & $(0.0084649)$ \\
\hline edu0 & edu1 & edu2 & edu3 & edu4 & edu5 & edu6 \\
\hline 0 & $0.3355767^{\star}$ & $0.8848721^{\star * *}$ & $1.634418^{\star * *}$ & $2.368382^{\star * *}$ & $3.816538^{* * *}$ & $4.835674^{\star * *}$ \\
\hline (omitted) & $(0.1783907)$ & $(0.1766723)$ & $(0.1747487)$ & $(0.1797852)$ & $(0.1760404)$ & $(0.2001004)$ \\
\hline mis1 & mis3 & $\begin{array}{c}\text { marital } \\
\text { status }\end{array}$ & _cons & $\mathrm{R} 2$ & $\mathrm{~N}$ & \\
\hline $0.1415186^{* * *}$ & $-0.0826352^{\star *}$ & $0.2784892^{\star * \star}$ & $5.297743^{\star * \star}$ & 0.3897 & 22748 & \\
\hline$(0.0479923)$ & $(0.0341031)$ & $(0.0339256)$ & $(0.2243216)$ & & & \\
\hline \multicolumn{7}{|c|}{ Quantile } \\
\hline \multicolumn{7}{|c|}{ Q10 } \\
\hline tenure & exper & exper2 & gender & age & firm sector & firm size \\
\hline $0.0321716^{* * *}$ & $0.100341^{\star * *}$ & $-0.0017752^{\star * *}$ & $-1.209208^{\star * *}$ & $-0.0250825^{\star * *}$ & $-0.1064166^{* * *}$ & $0.2364778^{\star * *}$ \\
\hline$(0.0029858)$ & $(0.0060906)$ & $(0.0000936)$ & $(0.050102)$ & $(0.003909)$ & $(0.0243009)$ & $(0.0127709)$ \\
\hline edu0 & edu1 & edu2 & edu3 & edu4 & edu5 & edu6 \\
\hline 0 & -0.1856663 & 0.1094527 & $0.6177948^{\star *}$ & $1.057156^{* * *}$ & $2.396798^{\star * *}$ & $3.715638^{* * *}$ \\
\hline (omitted) & $(0.2278249)$ & $(0.2334774)$ & $(0.246764)$ & $(0.2467355)$ & $(0.2552858)$ & $(0.3208794)$ \\
\hline mis1 & mis3 & $\begin{array}{c}\text { marital } \\
\text { status }\end{array}$ & _cons & $\mathbf{R}^{2}$ & $\mathrm{~N}$ & \\
\hline $0.1477148^{\star *}$ & $-0.1396655^{\star * *}$ & $0.1830903^{* * *}$ & $2.356181^{\star * *}$ & 0.1423 & 22748 & \\
\hline$(0.0676806)$ & $(0.0468143)$ & $(0.040315)$ & $(0.2882447)$ & & & \\
\hline
\end{tabular}

9 We thank an anonymous referee for the suggestion to include this section. 
Continued Table 4

\begin{tabular}{|c|c|c|c|c|c|c|}
\hline \multicolumn{7}{|c|}{ Q25 } \\
\hline tenure & exper & exper2 & gender & age & firm sector & firm size \\
\hline $0.0413111^{\star * *}$ & $0.1261627^{* * *}$ & $-0.0022112^{\star * *}$ & $-1.664919^{* * *}$ & $-0.0296445^{\star * *}$ & $-0.1133247^{* * *}$ & $0.2495299^{* * *}$ \\
\hline$(0.0028079)$ & $(0.0076901)$ & $(0.0001337)$ & $(0.0452171)$ & $(0.0041729)$ & $(0.0298882)$ & $(0.0113195)$ \\
\hline edu0 & edu1 & edu2 & edu3 & edu4 & edu5 & edu6 \\
\hline 0 & 0.0653056 & $0.5430536^{\star * *}$ & $1.222429^{* * *}$ & $1.93137^{\star * *}$ & $3.795588^{* * *}$ & $5.010843^{\star * *}$ \\
\hline (omitted) & $(.1442172)$ & $(.1459802)$ & $(.1468477)$ & $(.163691)$ & $(.1587857)$ & $(.1894876)$ \\
\hline mis1 & mis3 & $\begin{array}{c}\text { marital } \\
\text { status }\end{array}$ & _cons & $\mathrm{R}^{2}$ & $\mathbf{N}$ & \\
\hline $0.1384613^{* *}$ & -0.0631337 & $0.236402^{\star * *}$ & $3.354734^{\star * *}$ & 0.2438 & 22748 & \\
\hline$(0.0644439)$ & $(0.0471543)$ & $(0.040569)$ & $(0.2265432)$ & & & \\
\hline \multicolumn{7}{|c|}{ Q50 } \\
\hline tenure & exper & exper2 & gender & age & firm sector & firm size \\
\hline $0.0407096^{\star * *}$ & $0.1300071^{* * *}$ & $-0.0022457^{\star \star *}$ & $-1.839469^{\star * *}$ & $-0.0267553^{\star * \star}$ & $-0.1478047^{\star * *}$ & $0.2064136^{* * *}$ \\
\hline$(0.0025111)$ & $(0.0065625)$ & $(0.0000941)$ & $(0.0460521)$ & $(0.0037737)$ & $(0.0321244)$ & $(0.0112034)$ \\
\hline edu0 & edu1 & edu2 & edu3 & edu4 & edu5 & edu6 \\
\hline 0 & $0.3268053^{\star *}$ & $0.999363^{* * *}$ & $1.810998^{* * *}$ & $2.691691^{\star * *}$ & $4.295865^{\star * *}$ & $5.224763^{\star * *}$ \\
\hline (omitted) & $(0.1562686)$ & $(0.1519459)$ & $(0.1437213)$ & $(0.1455681)$ & $(0.1491036)$ & $(0.2037522)$ \\
\hline mis1 & mis3 & $\begin{array}{c}\text { marital } \\
\text { status }\end{array}$ & _cons & $\mathrm{R}^{2}$ & $\mathbf{N}$ & \\
\hline $0.1188001^{\star *}$ & $-0.1188404^{\star \star *}$ & $0.2618782^{\star * *}$ & $5.07478^{\star * *}$ & 0.2755 & 22748 & \\
\hline$(0.0602979)$ & $(0.0438662)$ & $(0.0390751)$ & $(0.2320751)$ & & & \\
\hline \multicolumn{7}{|c|}{ Q75 } \\
\hline tenure & exper & exper2 & gender & age & firm sector & firm size \\
\hline $0.0309616^{* * *}$ & $0.1223467^{\star * *}$ & $-0.002213^{* * *}$ & $-1.707621^{\star \star \star}$ & $-0.0149946^{\star * *}$ & $-.1916709^{\star * *}$ & $0.1238794^{* * *}$ \\
\hline$(0.0029751)$ & $(0.0074343)$ & $(0.0001069)$ & $(0.0472397)$ & $(0.0044888)$ & $(0.0297357)$ & $(0.0111866)$ \\
\hline edu0 & edu1 & edu2 & edu3 & edu4 & edu5 & edu6 \\
\hline 0 & $0.5235366^{\star *}$ & $1.230001^{\star * *}$ & $2.034593^{\star * *}$ & $2.764888^{\star * *}$ & $4.009525^{\star * *}$ & $4.850638^{\star * *}$ \\
\hline (omitted) & $(0.2305701)$ & $(0.230956)$ & $(0.2293899)$ & $(0.2233697)$ & $(0.2259386)$ & $(0.254467)$ \\
\hline mis1 & mis3 & $\begin{array}{c}\text { marital } \\
\text { status }\end{array}$ & _cons & $\mathrm{R}^{2}$ & $\mathrm{~N}$ & \\
\hline $0.1152762^{\star \star}$ & $-0.1093143^{\star \star}$ & $0.2727937^{\star \star \star}$ & $6.939095^{\star * *}$ & 0.2322 & 22748 & \\
\hline$(0.0565842)$ & $(0.043422)$ & $(0.0405922)$ & $(0.34563)$ & & & \\
\hline \multicolumn{7}{|c|}{ Q90 } \\
\hline
\end{tabular}


Continued Table 4

\begin{tabular}{ccccccc}
\hline tenure & exper & exper2 & gender & age & firm sector & firm size \\
\hline $0.023178^{* * *}$ & $0.0855561^{* * *}$ & $-0.0015764^{* * *}$ & $-1.228933^{* * *}$ & $-0.009448^{* *}$ & $-0.1963498^{* * *}$ & $0.0409481^{* * *}$ \\
\hline$(0.0028014)$ & $(0.0087128)$ & $(0.0001381)$ & $(0.0463183)$ & $(0.0047169)$ & $(0.0302482)$ & $(0.0124981)$ \\
\hline edu0 & edu1 & edu2 & edu3 & edu4 & edu5 & edu6 \\
\hline 0 & $0.6926056^{* *}$ & $1.433658^{* * *}$ & $1.968435^{* * *}$ & $2.407889^{* * *}$ & $3.35263^{* * *}$ & $3.991848^{\star * *}$ \\
\hline$($ omitted $)$ & $(.3365277)$ & $(0.3275334)$ & $(0.3221446)$ & $(0.3216224)$ & $(0.3083418)$ & $(0.3445096)$ \\
\hline mis1 & mis3 & $\begin{array}{c}\text { marital } \\
\text { status }\end{array}$ & _cons & $\mathrm{R}^{2}$ & $\mathrm{~N}$ & \\
\hline $0.1671546^{* *}$ & 0.0570462 & $0.2460854^{* * *}$ & $8.187674^{* * *}$ & 0.1518 & 22748 & \\
\hline$(0.070113)$ & $(0.040461)$ & $(0.0446226)$ & $(0.3447342)$ & & & \\
\hline
\end{tabular}

In these regressions, with more than 22,700 observations, all of the variables have the expected signs and with high statistical significance. An additional year of tenure implies a nearly $0.4 \%$ increase in wages (also in the quantile median regression), while an additional year of experience implies nearly a $1.3 \%$ increase in wages, but this effect tends to decrease after 57 years (with similar effects obtained in the median regression. Women tend to earn $17 \%$ less (to $18.4 \%$ when resulting from the median regression) than men. Wages decrease nearly $2.7 \%$ for every year of age, decrease $1.79 \%$ (nearly $1.48 \%$ from the median regression coefficient) when passing from the private sector to the non-private sector, increase $1.87 \%$ with the firm size (2.06\% from the median regression), and increase $2.78 \%$ if married $(2.62 \%$ from the median regression). Interestingly, in this pooled regression, all of the education dummies included have a positive sign, meaning that there is a positive effect of education of all ISCED levels, in both the OLS and quantile regressions. Finally, but mostly important in this paper, under-skilled workers earn $1.42 \%$ more and over-skilled earn $0.83 \%$ less. From the median regression, under-skilled workers earn almost $1.19 \%$ more, the same percentage by which the over-skilled earn less. Contrary to what we saw in most individual countries, these effects are now highly statistically significant.

\section{Effects of Over-skilling and} Under-skilling

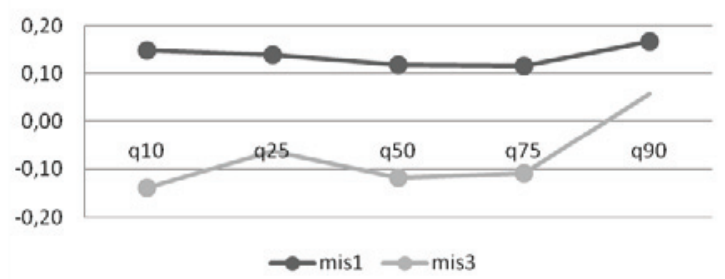

Fig. 2. Figures with the evolution of coefficients for under-skilling (mis1) and over-skilling (mis3) throughout the wage distribution for the pooled regression. Bullets in the graphs indicate statistically significant estimates ( $10 \%$ or higher level of significance) 
From the quantile regression we can observe that variable effects on wages are almost constant throughout the distribution. The next figure (Fig. 2) shows the evolution of the effects of being over-skilled or under-skilled throughout the distribution of wages.

\section{Conclusions}

We studied the relationship between mismatch in workers' skills and labour market requirements in different European Countries. Although a vast literature reports the effects of over- and under-education on wages, the effects of mismatch in skills is less studied. We found evidence according to which over-skilled workers tend to have a wage penalty and under-skilled workers tend to have a premium. This evidence complements the prevailing evidence on the issue. However, although we obtained the typical effects of education, tenure, experience, and gender on wages, the effects of mismatch between skills and labour market requirements differ considerably across the wage distribution and countries. Quantitatively, the wage premiums and penalties due to mismatch seem to be important when compared with the effects of tenure, experience, and (even) education.

This is the first attempt to compare mismatch (under-skilling and over-skilling) across different European countries and tends to confirm an over-skilling penalty reported in papers that studied individual countries. It also reinforces a result that is rare in the literature, which is a premium for under-skilled workers. Thus, it confirms a stylized fact according to which over-skilled workers tend to have a wage penalty and under-skilled workers have a wage premium. Although it may be arguable that such a result is due to transitional phenomena, the theoretical explanation for these effects on wages are not yet well understood. This may be a path to future research. A potentially interesting way to follow up the research reported here would be to test the psychological-based approach of Tsang and Levin (1985) to explain both the effects of over-skilling and under-skilling on wages.

\section{Acknowledgement}

The authors acknowledge comments from Alexandra Ferreira Lopes and financial support from Fundação para a Ciência e Tecnologia through Project PTDC/EGE-ECO/112499/2009 Mismatches in the Labor Market and Productivity Differences.

\section{References}

Alen, J.; Velden, R. 2001. Educational mismatches versus skill mismatches: effects on wages, job satisfaction and on-the-job search, Oxford Economic Papers 53(3): 434-452. http://dx.doi.org/10.1093/oep/53.3.434

Budria, S.; Moro-Egido, A. 2008. Education, educational mismatch and wage inequality: evidence for Spain, Economics of Education Review 27(3): 332-341. http://dx.doi.org/10.1016/j.econedurev.2006.10.005

Buchinsky, M. 1995. Estimating the asymptotic covariance matrix for quantile regression models: a Monte Carlo study, Journal of Econometrics 65(1): 109-54. http://dx.doi.org/10.1016/0304-4076(94)01599-U

Buchinsky, M. 1998. Recent advances of quantile regression: a practical guideline for empirical research, Journal of Human Resources 33(1): 88-126. http://dx.doi.org/10.2307/146316 
Cardoso, A. 2004. Jobs for young university graduates: is it worth having a degree? IZA Discussion Papers 1311. Institute for the Study of Labor (IZA).

Cohn, E.; Khan, S. 1995. The wage effects of overschooling revisited, Labour Economics 2(1): 67-76. http://dx.doi.org/10.1016/0927-5371(95)80008-L

Dolton, P.; Silles, M. 2008. The Effects of overeducation on earnings in the graduate labor market, Economics of Education Review 27(2): 125-139. http://dx.doi.org/10.1016/j.econedurev.2006.08.008

Eurofound 2012. Trends in job quality in Europe. Publications Office of the European Union, Luxembourg.

Guironnet, J.; Peypoch, N. 2007. Human capital allocation and overeducation: a measure of French productivity, Economic Modelling 24(3): 398-410. http://dx.doi.org/10.1016/j.econmod.2006.09.003

Hartog, J. 2000. Over-education and earnings: where are we, where should we go?, Economics of Education Review 19(2): 131-147. http://dx.doi.org/10.1016/S0272-7757(99)00050-3

Koenker, R.; Hallock, K. 2001. Quantile regression: an introduction, Journal of Economic Perspectives 15(4): 143-56. http://dx.doi.org/10.1257/jep.15.4.143

Kiker, B.; Santos, M.; Mendes de Oliveira, M. 1997. Overeducation and undereducation: evidence for Portugal, Economics of Education Review 16(2): 111-125. http://dx.doi.org/10.1016/S0272-7757(96)00040-4

Kunze, A. 2000. The determination of wages and the wage gender gap: a survey. IZA DP 193, August. 76 p.

Lamo, A.; Messina, J. 2010. Formal education, mismatch and wages after transition: assessing the impact of unobserved heterogeneity using matching estimators, Economics of Education Review 29(6): 1086-1099. http://dx.doi.org/10.1016/j.econedurev.2010.06.002

McGoldrick, K.; Robst, J. 1996. Gender differences in overeducation: a test of the theory of differential overualification, American Economic Review 86(2): 280-284.

McGuiness, S.; Sloane, P. 2011. Labour market mismatch among UK graduates: an analysis using REFLEX data, Economics of Education Review 30(1): 120-145.

http://dx.doi.org/10.1016/j.econedurev.2010.07.006

Miller, J.; Rodgers, Y. 2008, Economic importance and statistical significance: guidelines for communication empirical research, Feminist Economics 14(2): 117-149. http://dx.doi.org/10.1080/13545700701881096

Muysken, J.; Ter Weel, B. 2000. Overeducation and crowding out of low-skilled workers, in Borghans, L.; de Grip, A. (Eds.). The Overeducated Worker? The Economics of Skill Utilization. Edward Elgar Publishers, 109-132.

Parent-Thirion, A.; Fernández Macías, E.; Hurley, E.; Vermeylen, G. 2007. Fourth European Working Conditions Survey. Luxembourg: Office for Official Publications of the European Communities. $139 \mathrm{p}$.

Ordine, P.; Rose, G. 2011. Inefficient self-selection into education and wage inequality, Economics of Education Review 30(4): 582-597. http://dx.doi.org/10.1016/j.econedurev.2011.03.007

Robst, J. 2007. Education and job match: the relatedness of College Major and work, Economics of Education Review 26(4): 397-407. http://dx.doi.org/10.1016/j.econedurev.2006.08.003

Rubb, S. 2003. Overeducation in the labor market: a comment and re-analysis of a meta-analysis, Economics of Education Review 22(6): 621-629. http://dx.doi.org/10.1016/S0272-7757(02)00077-8

Sicherman, N. 1991. Overeducation in the labor market, Journal of Labor Economics 9(2): 101-122. http://dx.doi.org/10.1086/298261

Sloane, P.; Battu, H.; Seaman, P. 1999. Overeducation, undereducatoion and the British labour market, Applied Economics 31(11): 1437-1453. http://dx.doi.org/10.1080/000368499323319

Tsai, Y. 2010. Returns to overeducation: a longitudinal analysis of the U.S. labor market, Economics of Education Review 29(4): 606-617. http://dx.doi.org/10.1016/j.econedurev.2010.01.001

Tsang, M.; Levin, H. 1985. The economics of overeducation, Economics of Education Review 4(2): 93-104. http://dx.doi.org/10.1016/0272-7757(85)90051-2 
离|

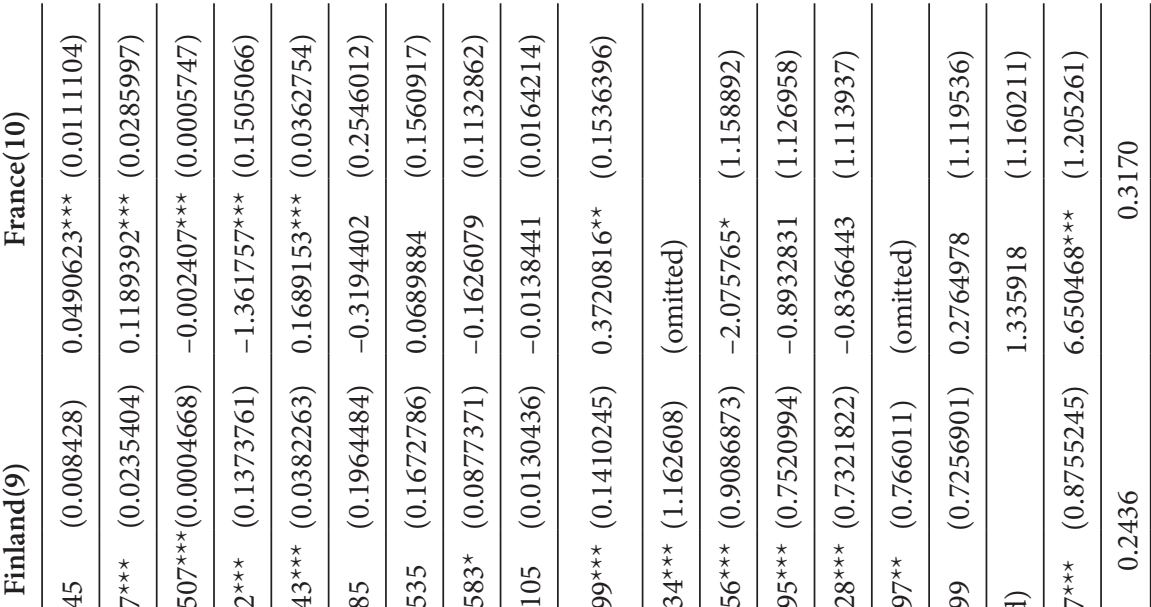

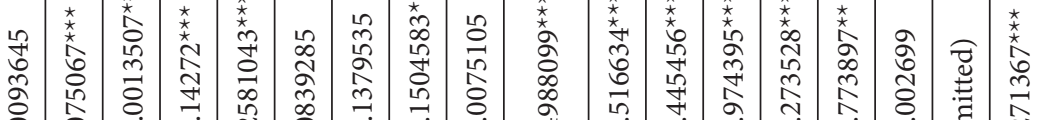

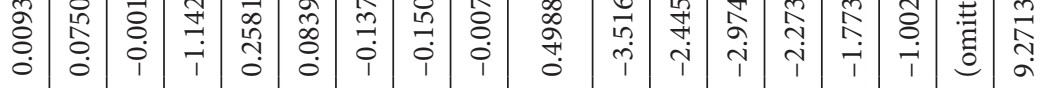

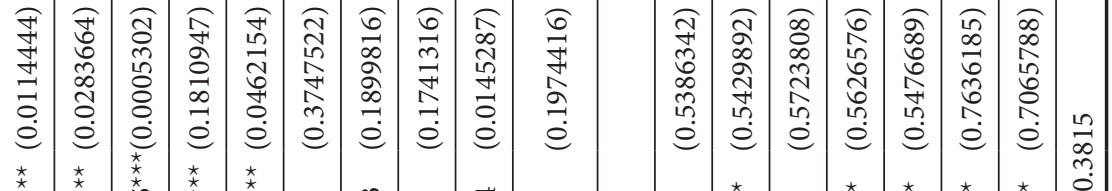

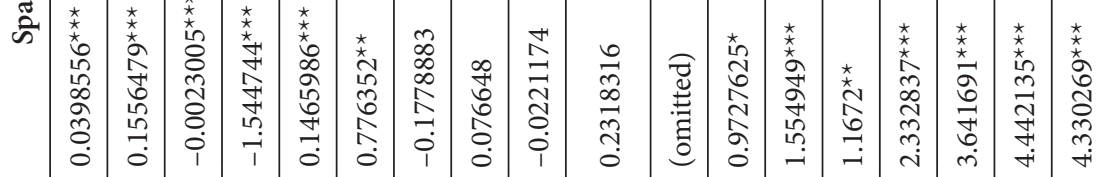

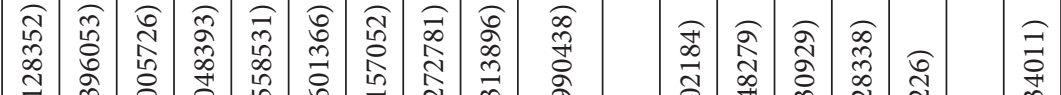

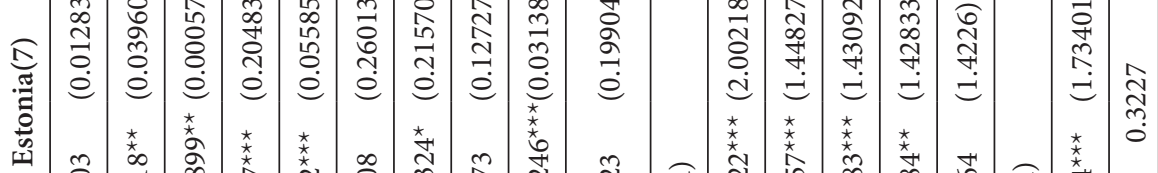

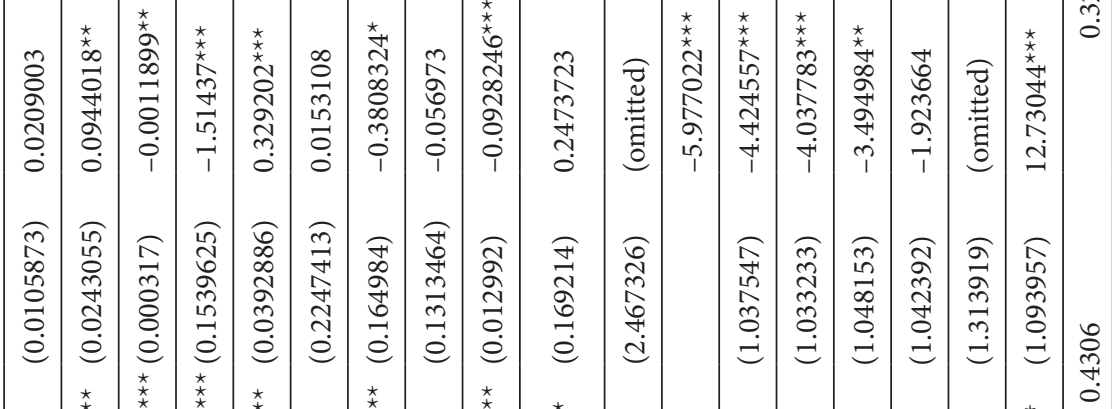

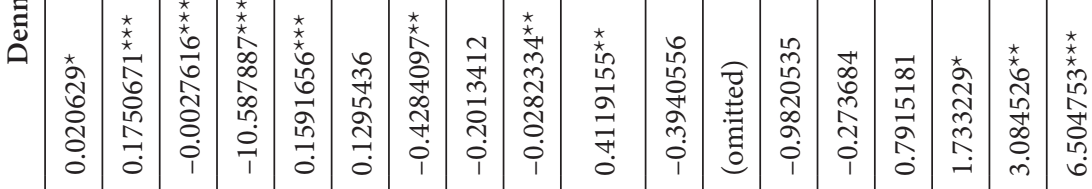

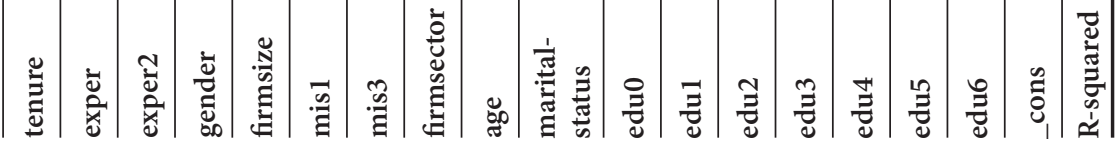




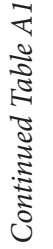

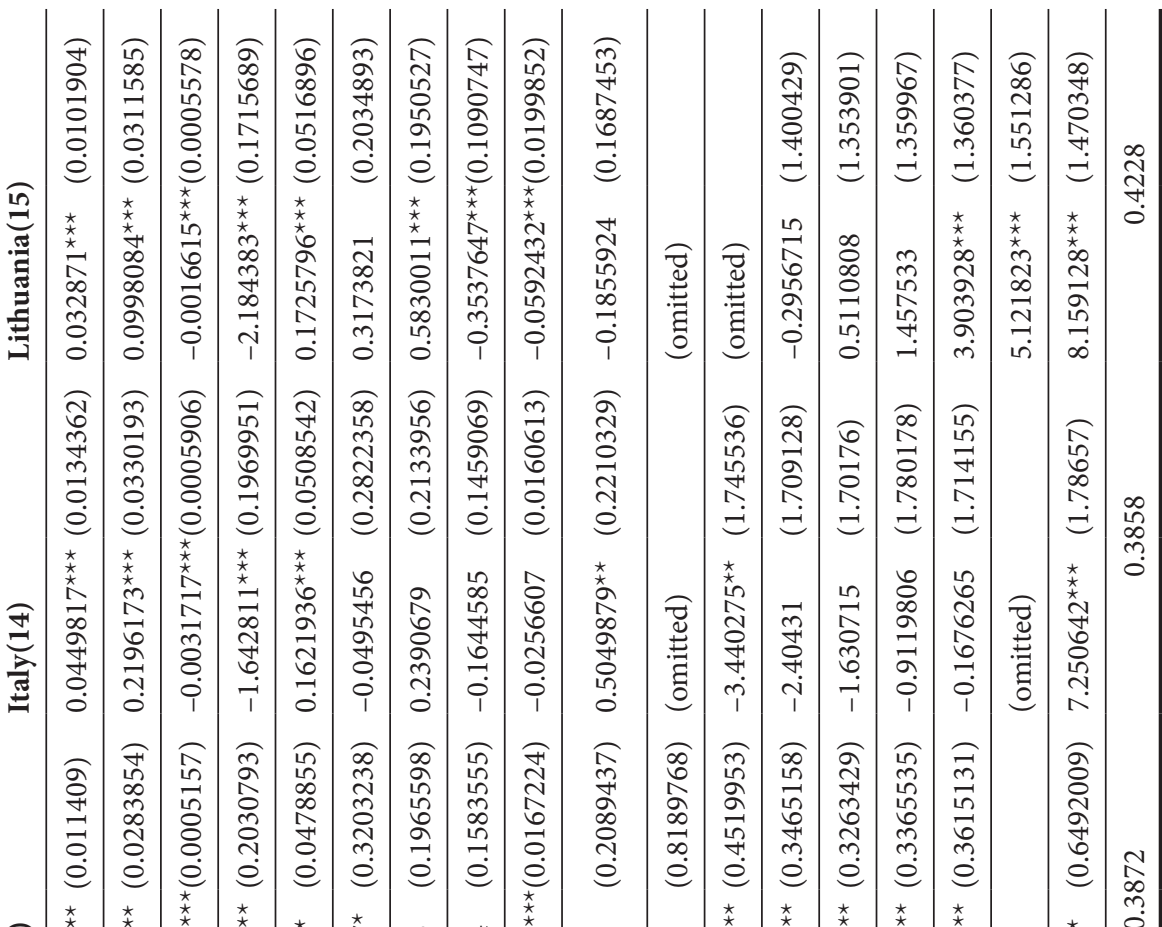

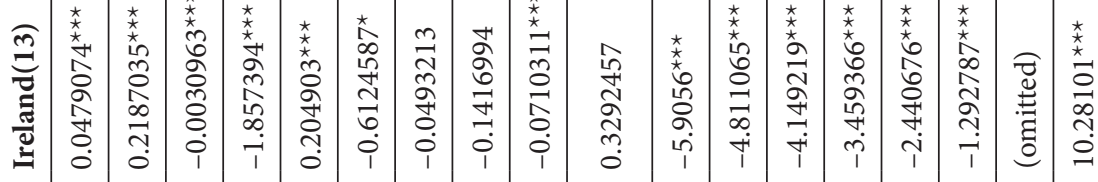

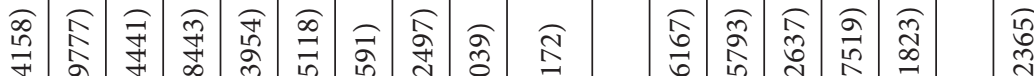

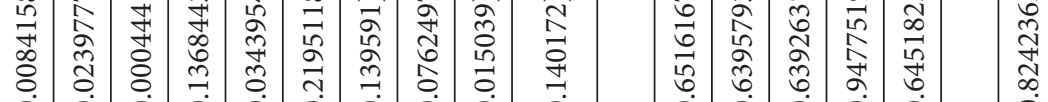

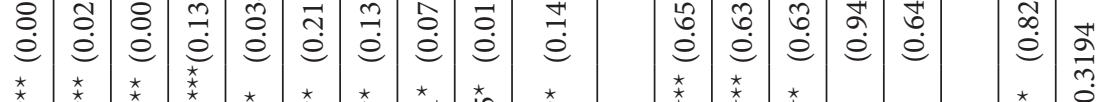

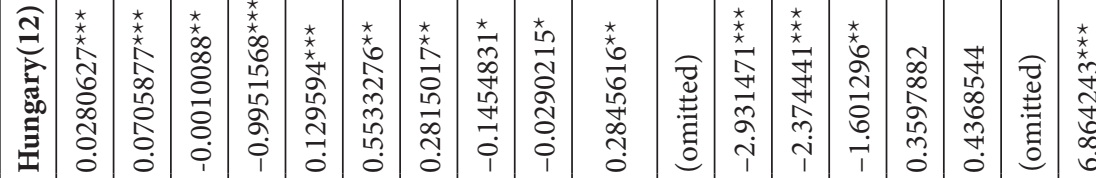

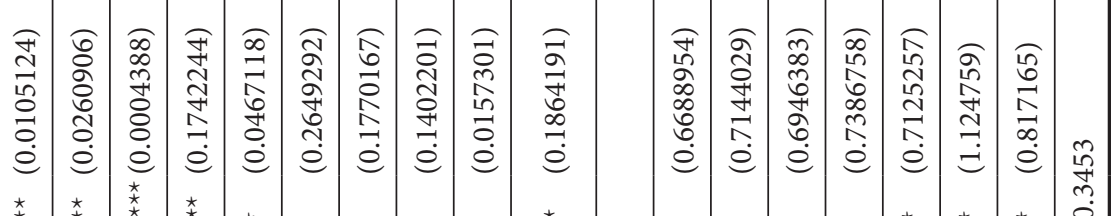

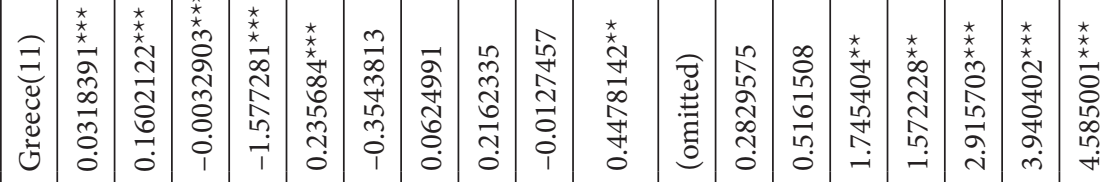

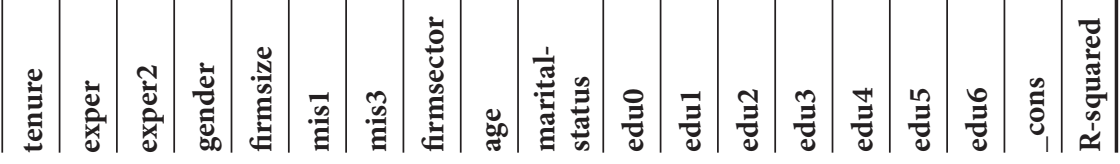


产
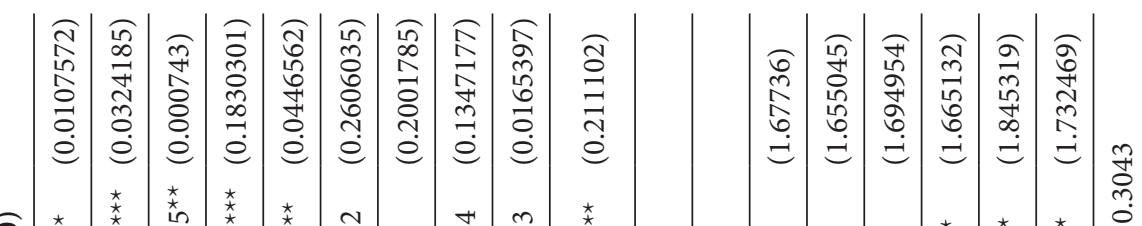

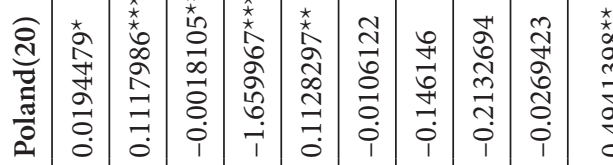

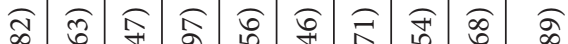

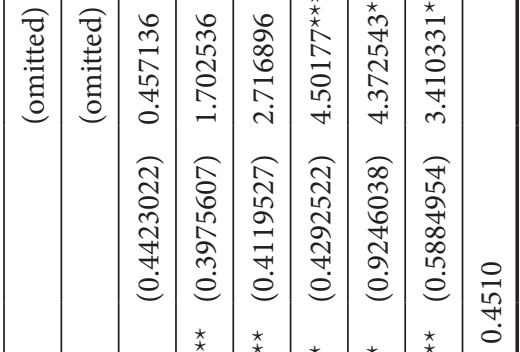

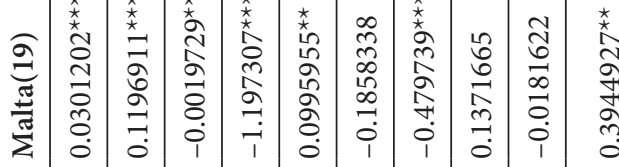

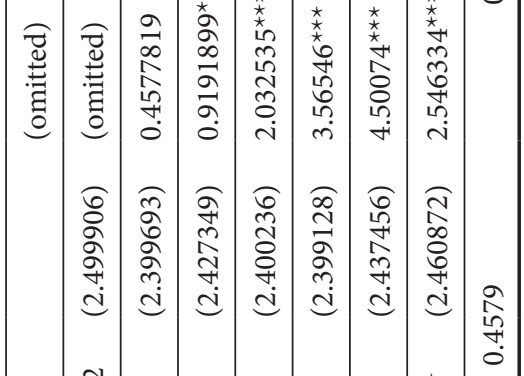

旁

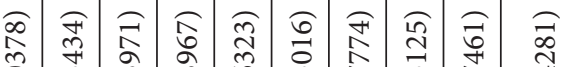

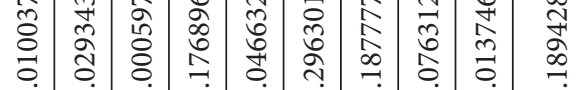

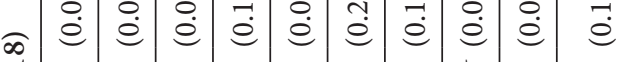

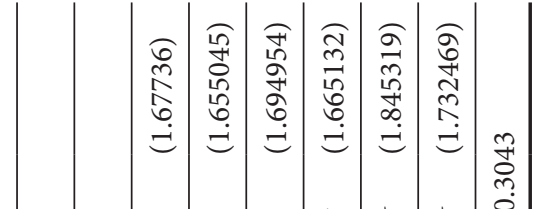

○)

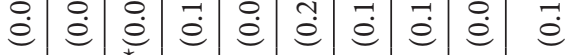

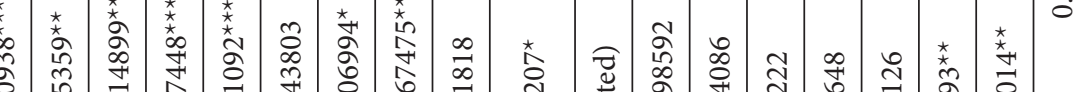

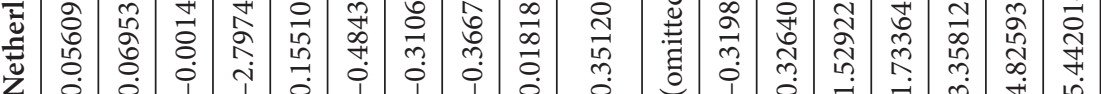

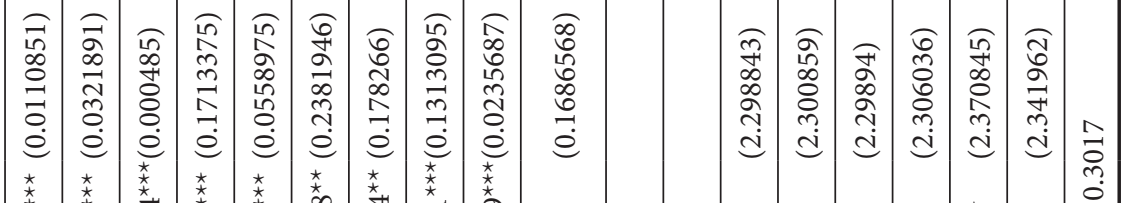

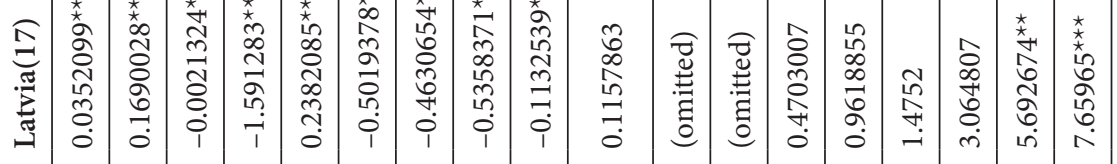

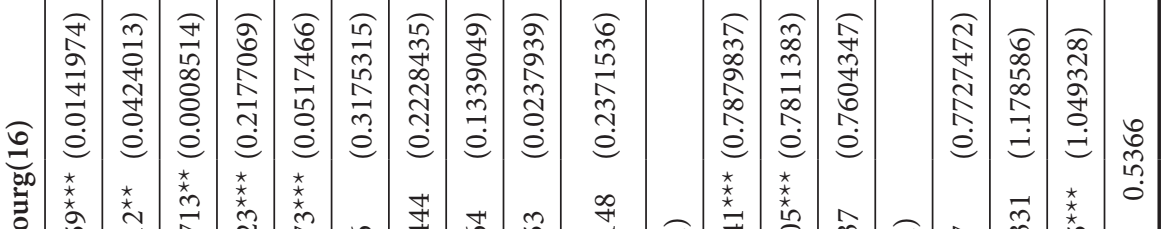

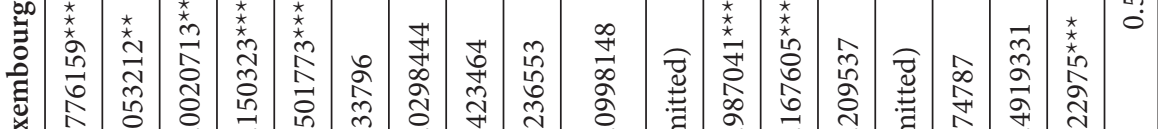

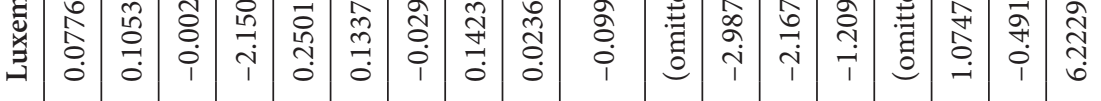

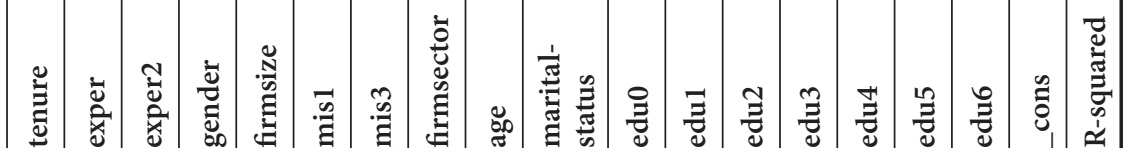


章

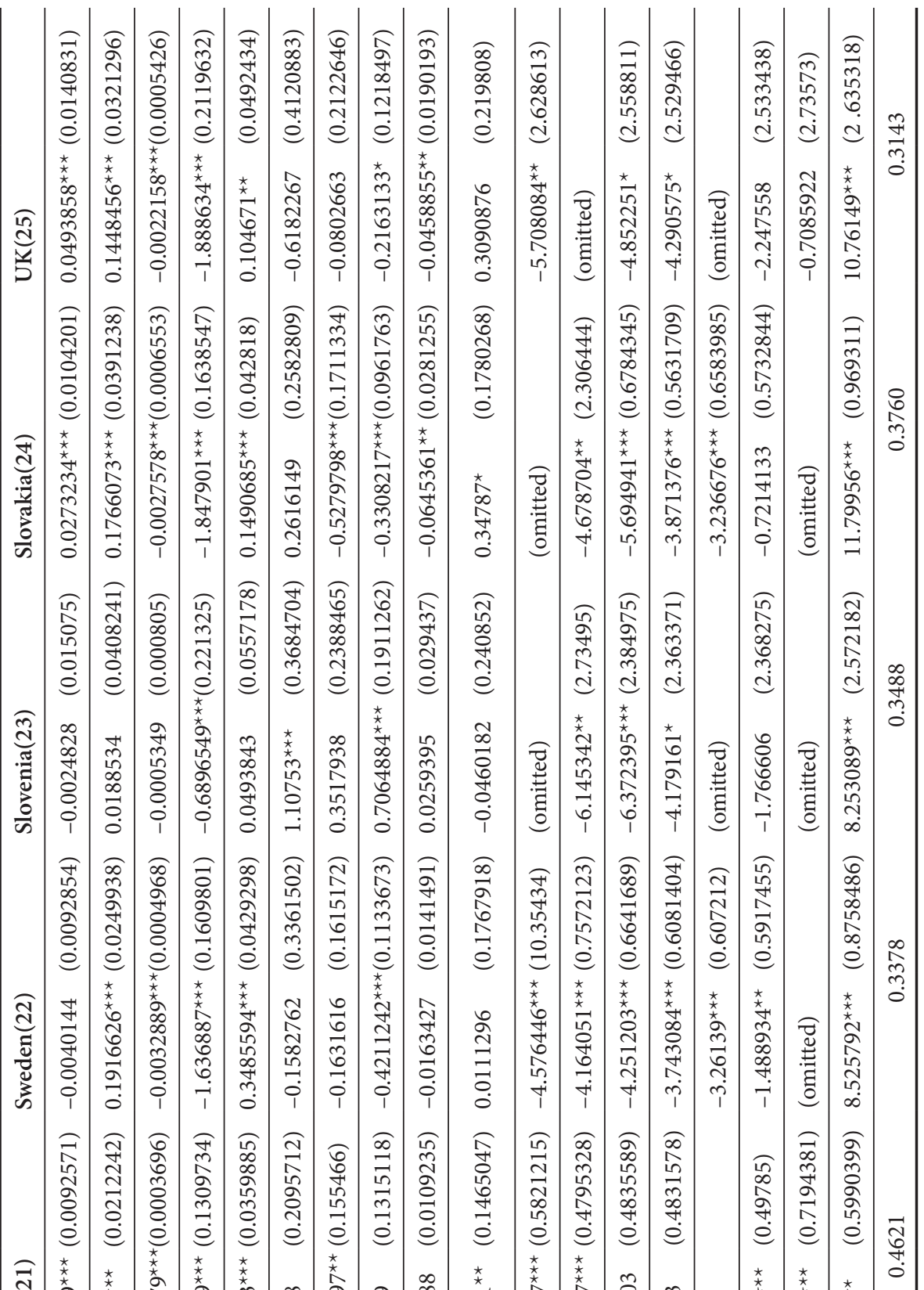

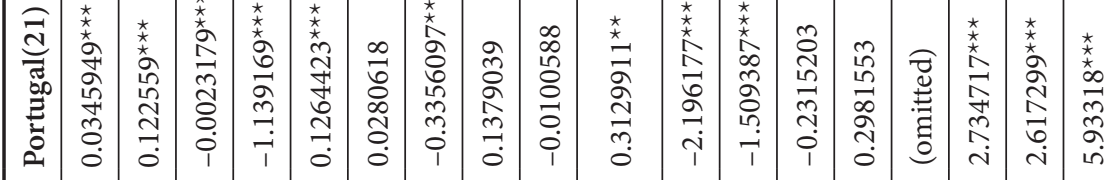

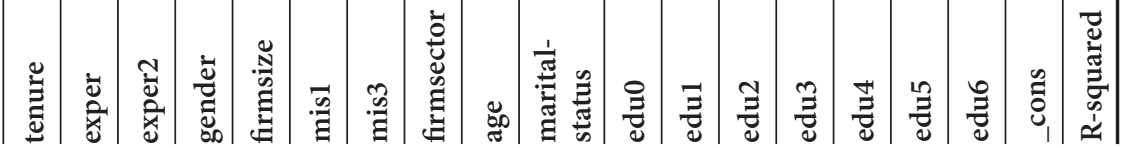


离

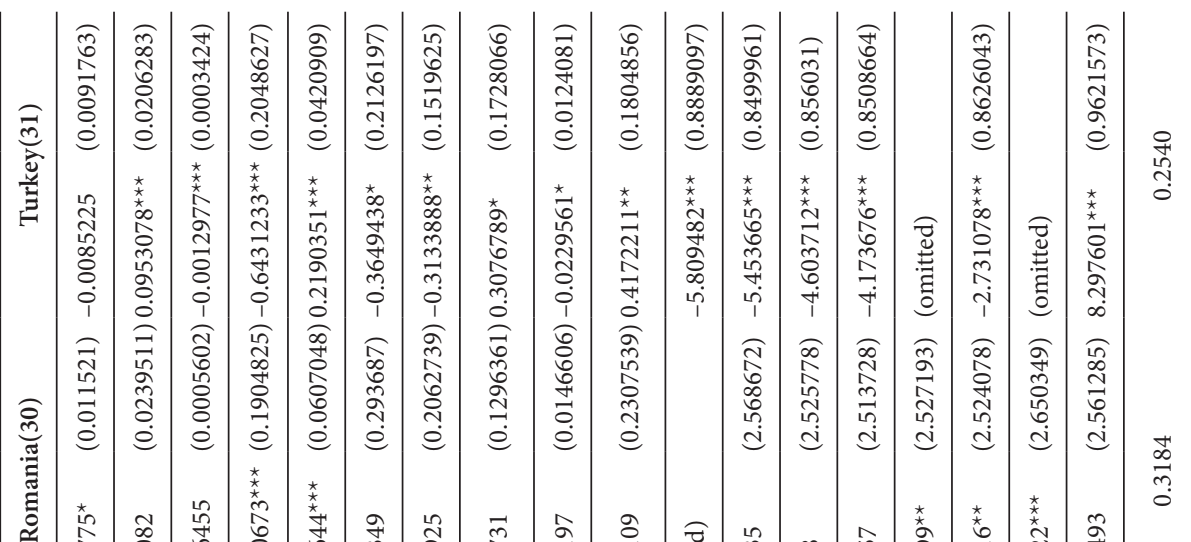

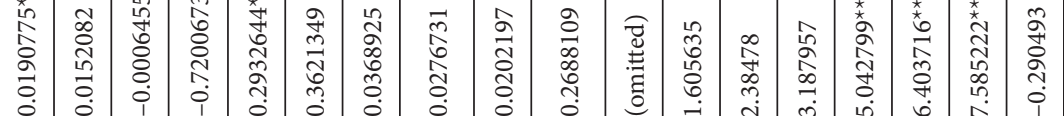

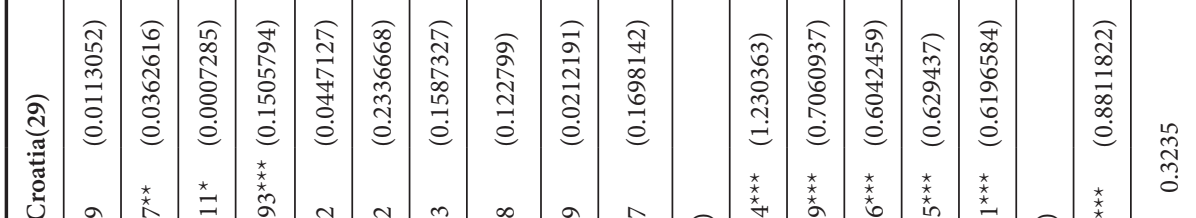

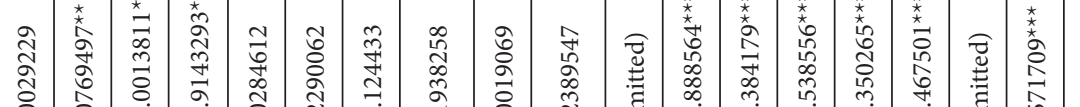

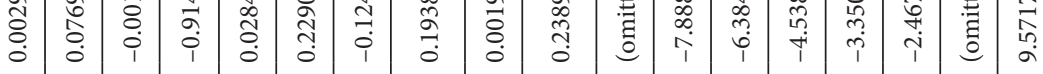

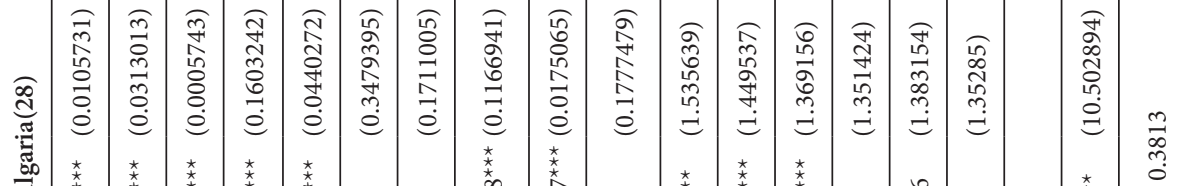

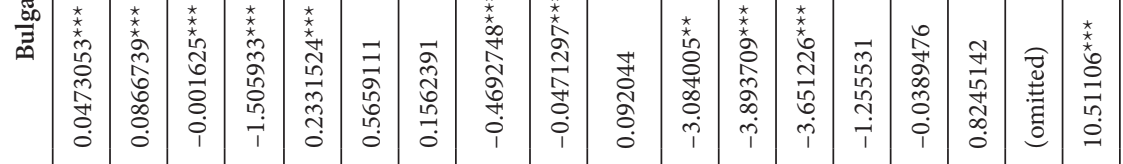

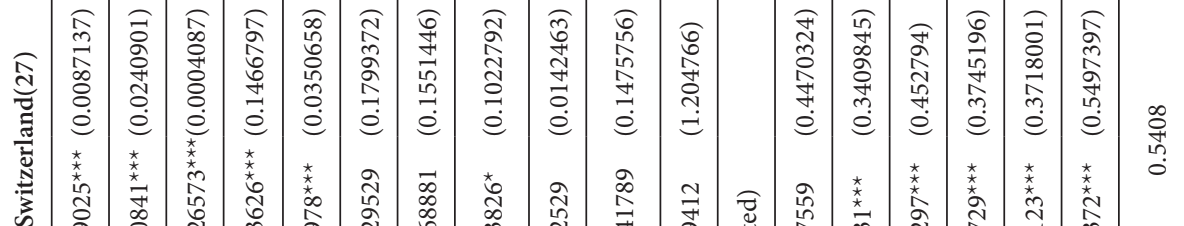

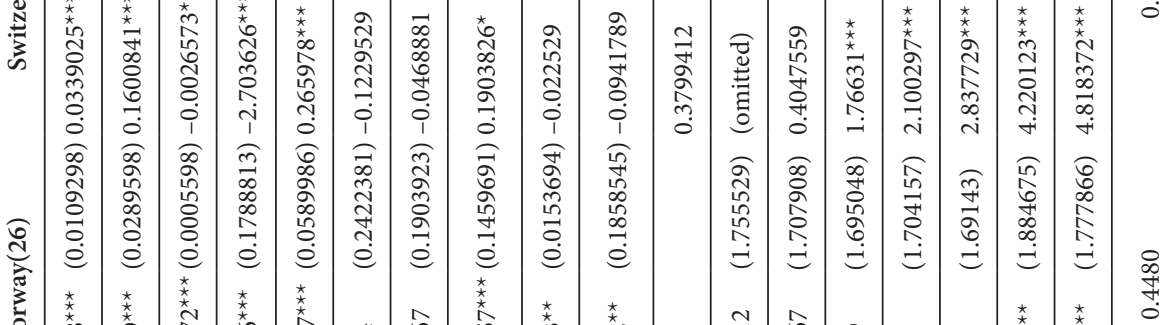

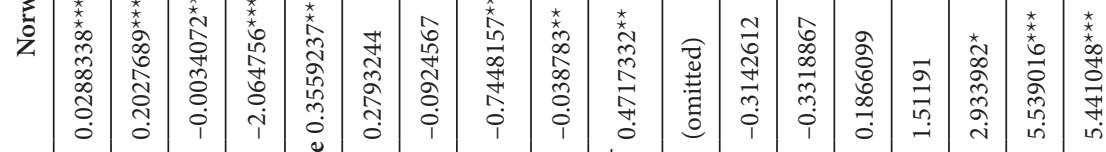

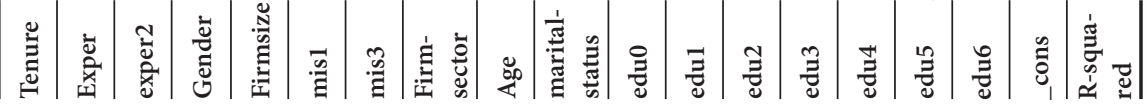


S448 M. Santos, T. N. Sequeira. Skills mismatch and wage inequality: evidence for different...

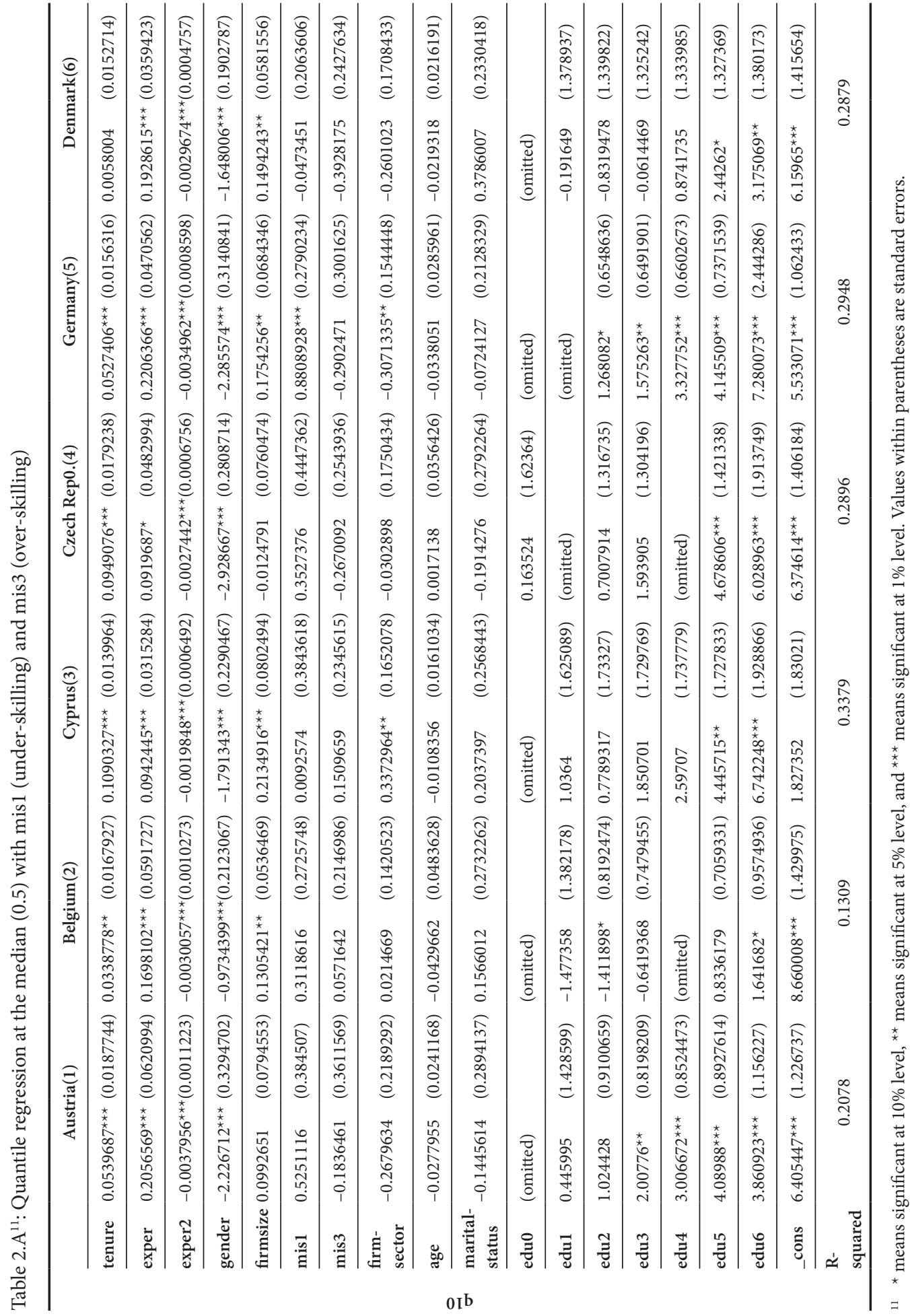


离

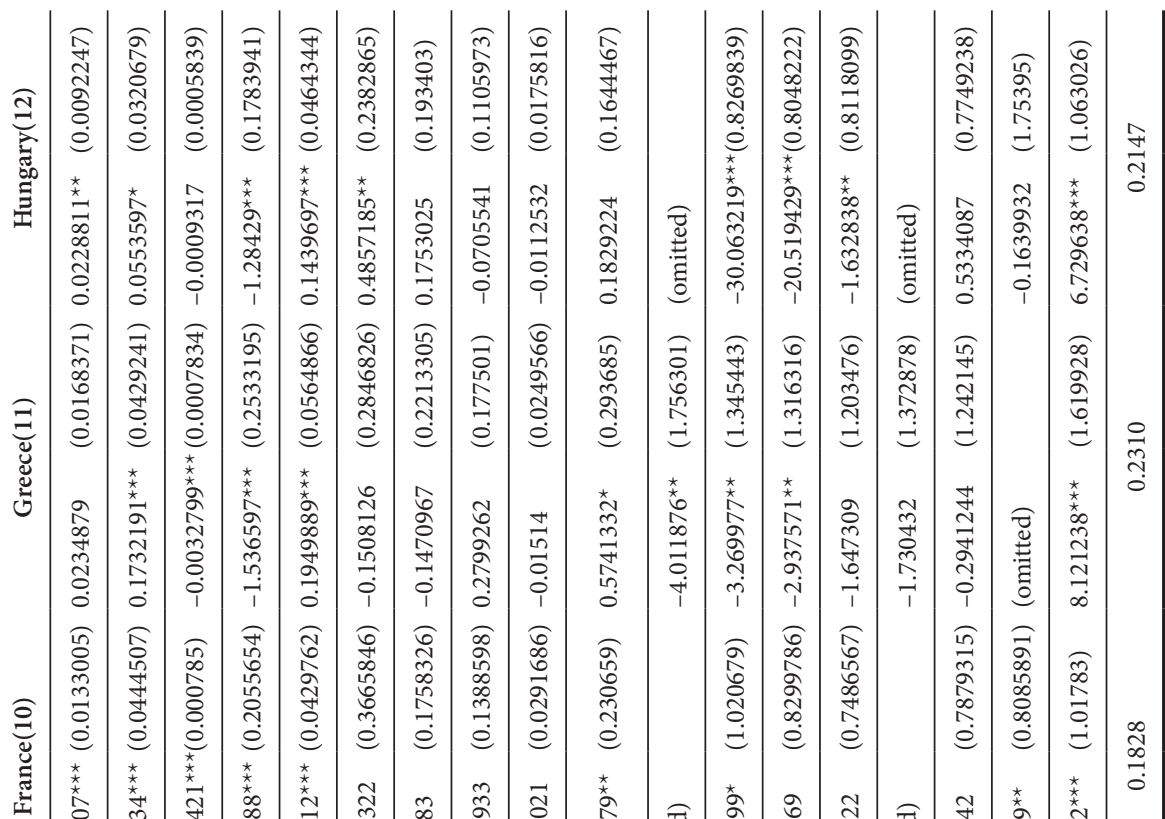

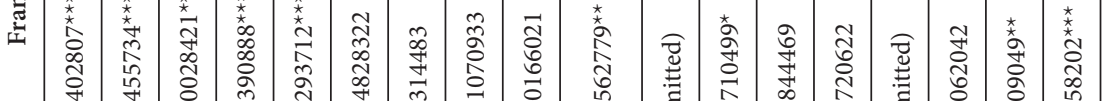

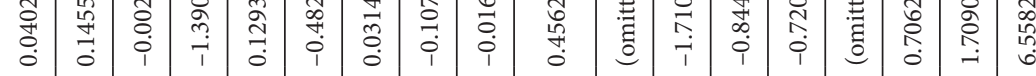

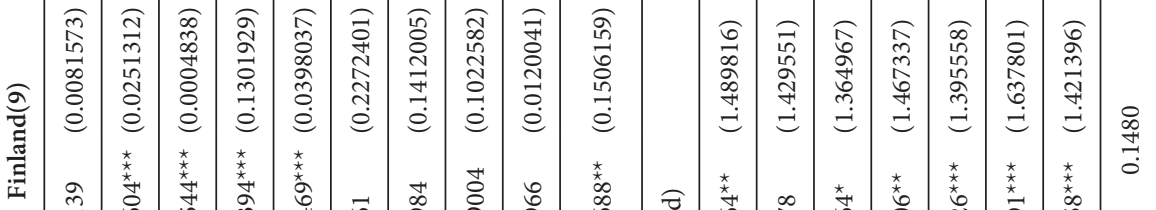

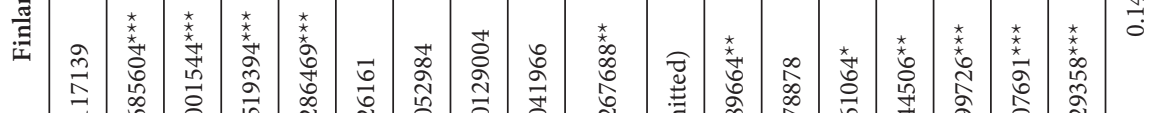

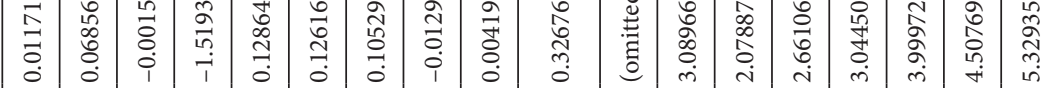

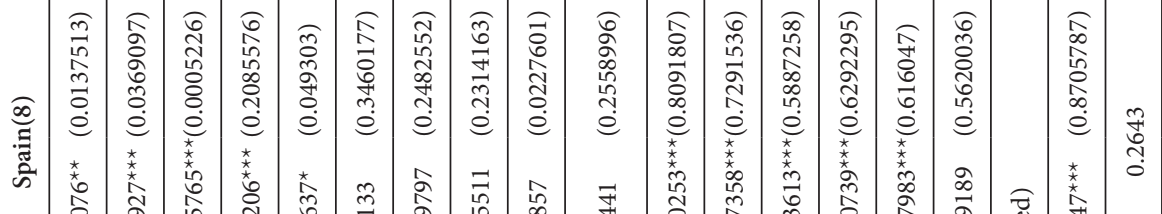

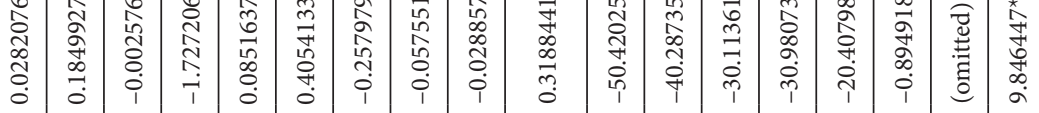

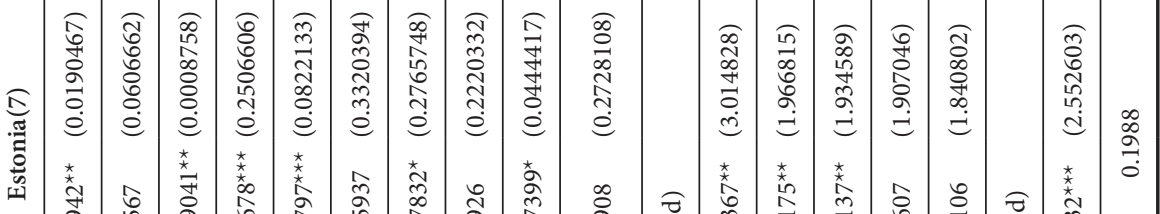

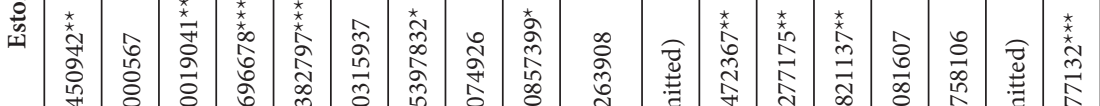

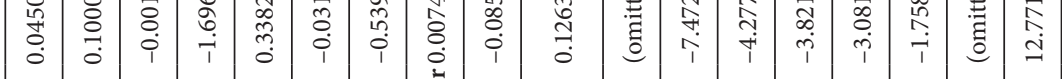

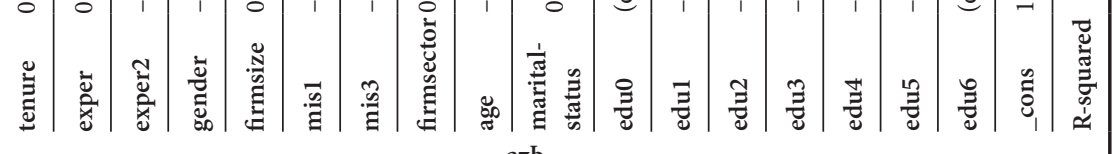




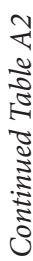

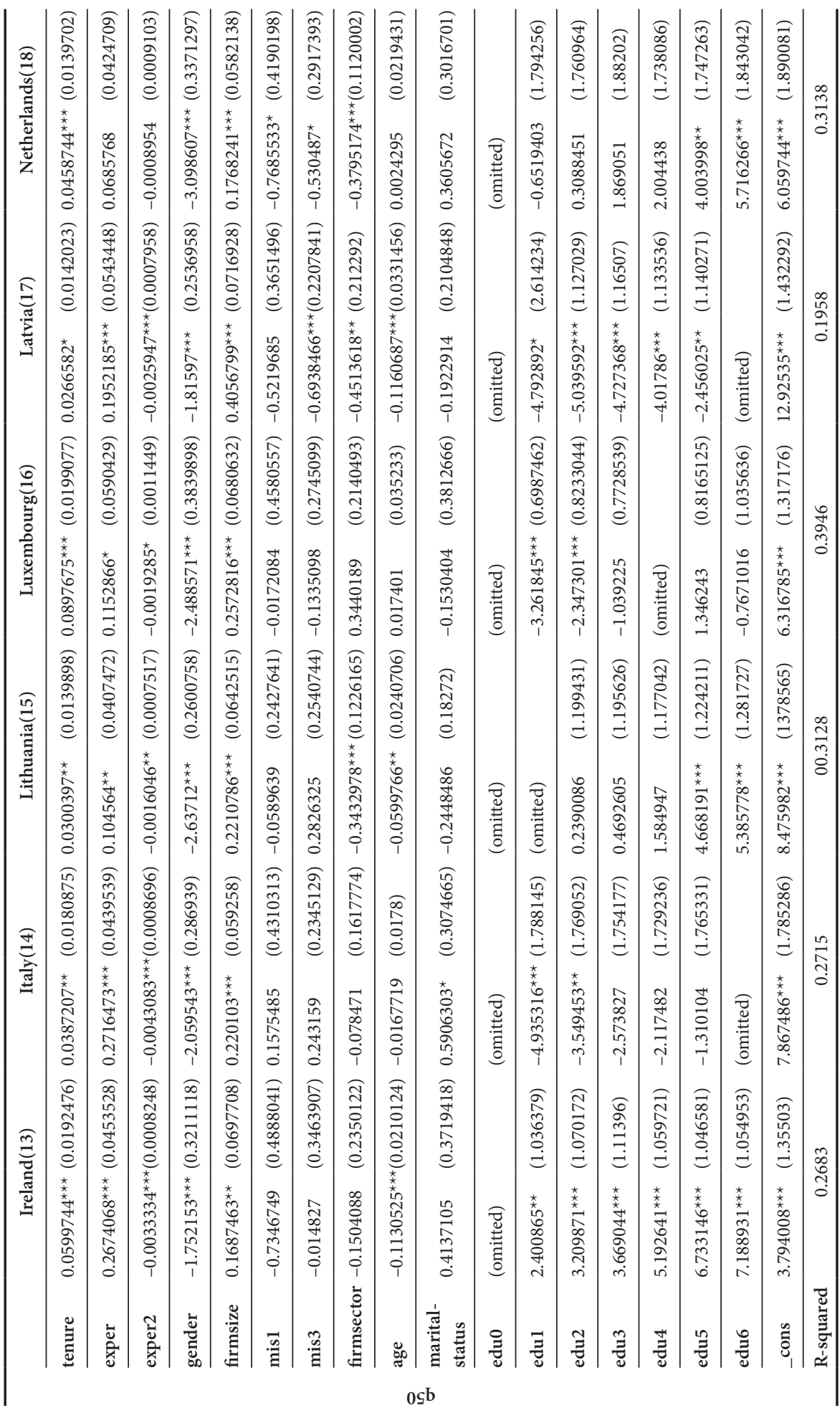




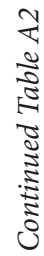

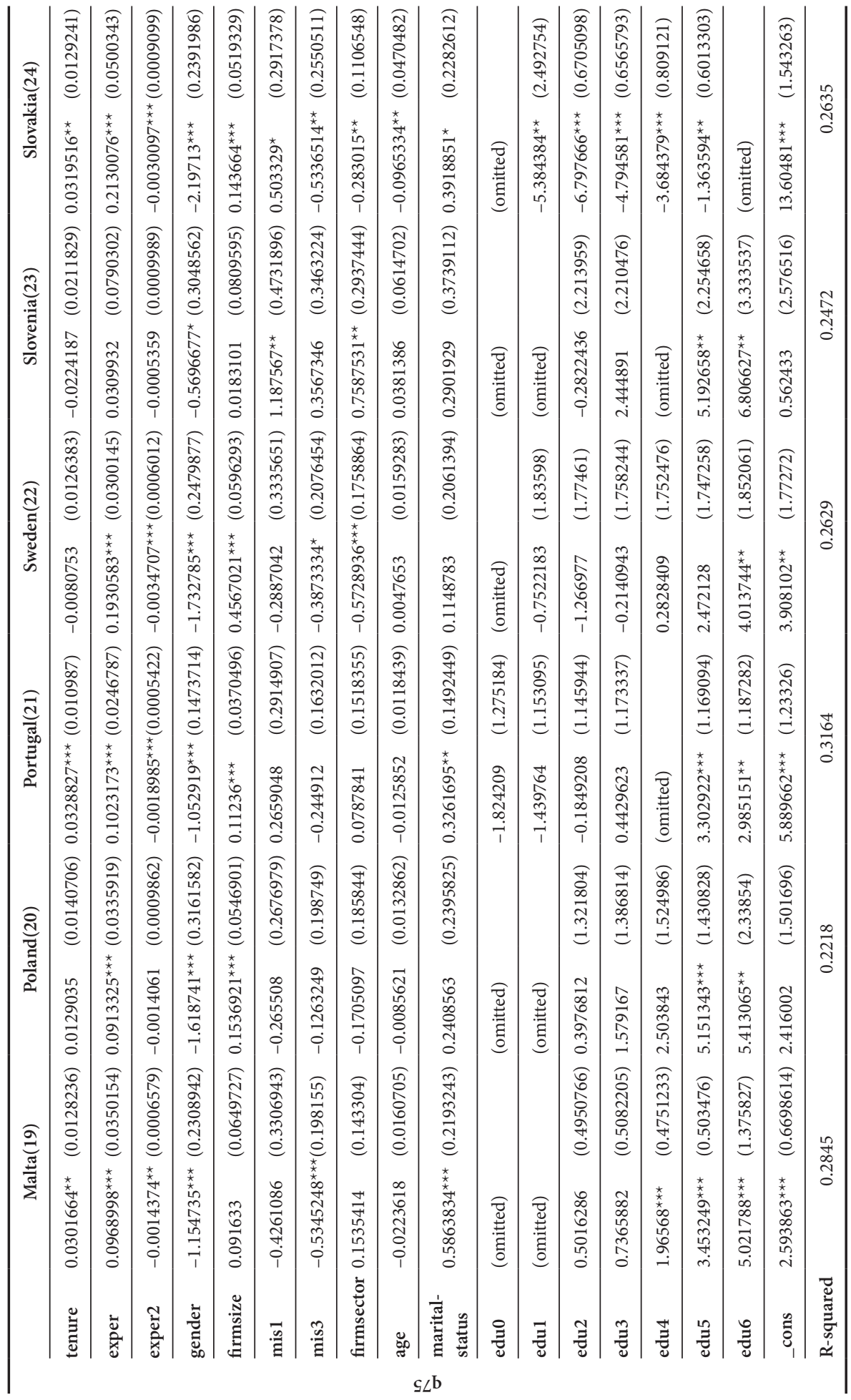


ปै

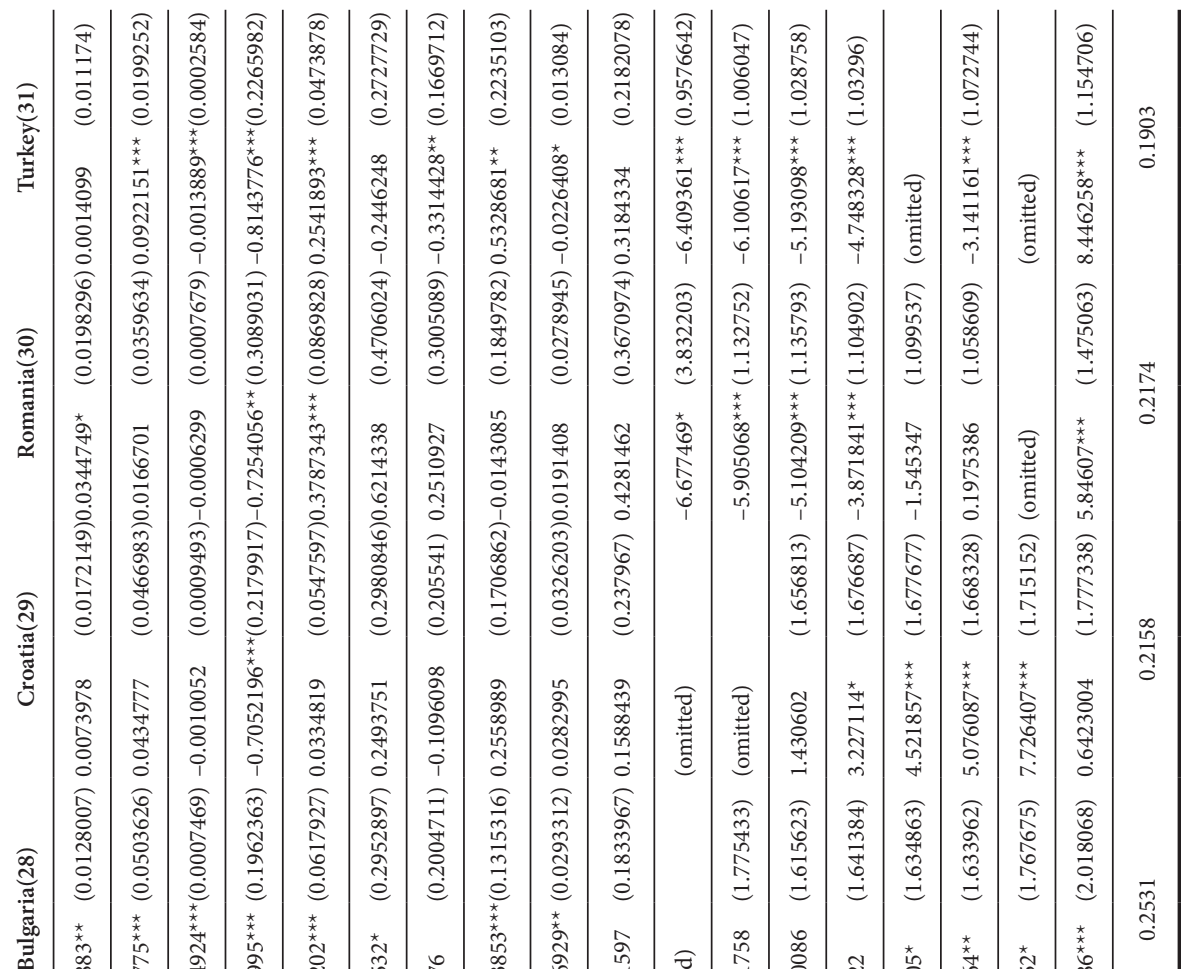

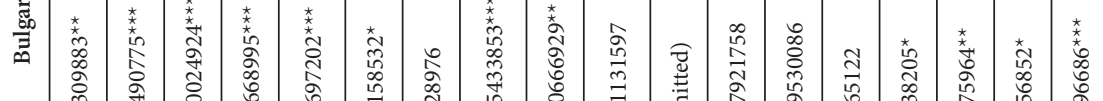

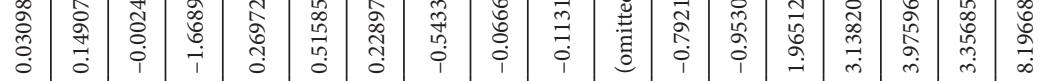

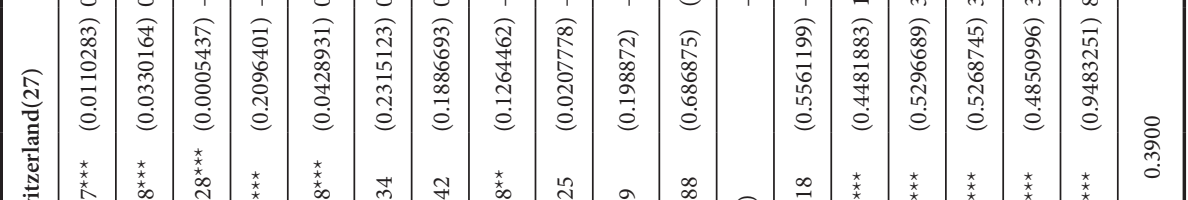

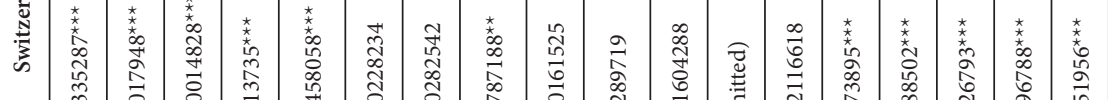

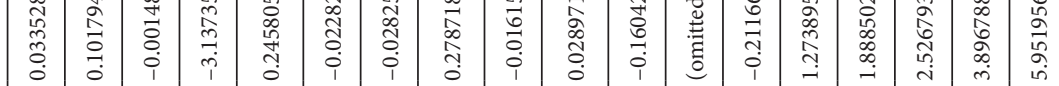

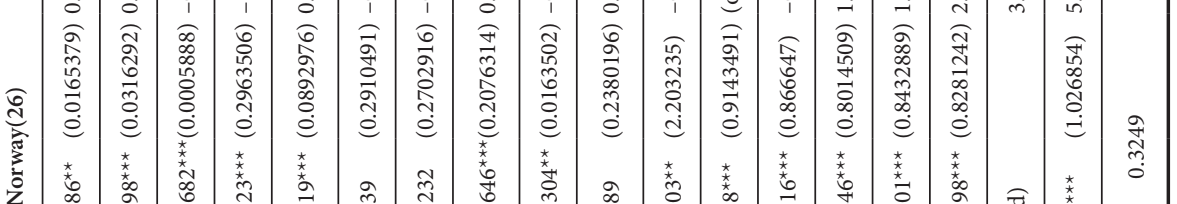

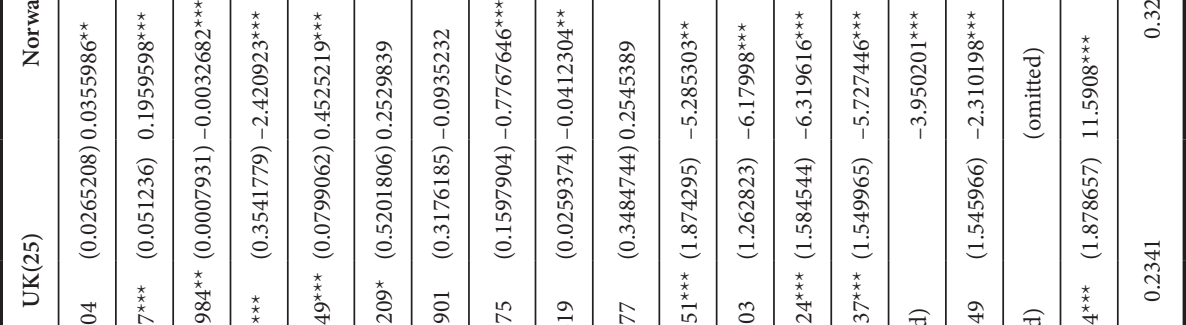

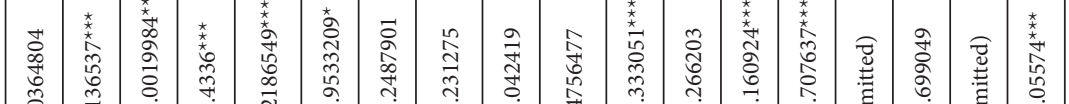

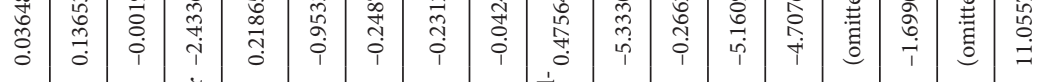

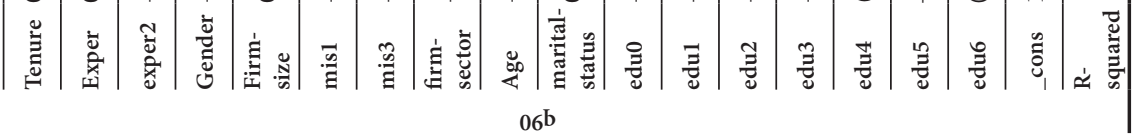


Marcelo SANTOS. He has a Master's in Economics and is a PhD Student in Economics at Universidade da Beira Interior, Covilhã, Portugal, being also affiliated with CEFAGE-UBI research unit. His research interests lie in the areas of economic growth and development and labor economics.

Tiago Neves SEQUEIRA. He has a PhD in Economics (Nova School of Business and Economics). He has been working on the theory of Endogenous Economic Growth and on empirical applications of that theory. He is currently employed at Universidade da Beira Interior, Portugal, being also affiliated with CEFAGE-UBI research unit. His research interests lie in the areas of macroeconomics (economic growth and business cycles), economics of education and applied economics. 